\title{
Early establishment of vertebrate trophic interactions: Food web structure in Middle to Late Devonian fish assemblages with exceptional fossilization
}

\author{
MARION CHEVRINAIS, ClAIRE JACQUeT \& RICHARD CLOUTIER
}

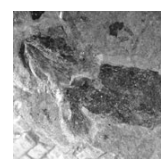

\begin{abstract}
In past and present ecosystems, trophic interactions determine material and energy transfers among species, regulating population dynamics and community stability. Food web studies in past ecosystems are helpful to assess the persistence of ecosystem structure throughout geological times and to explore the existence of general principles of food web assembly. We determined and compared the trophic structure of two Devonian fish assemblages [(1) the Escuminac assemblage (ca. $380 \mathrm{Ma}$ ), Miguasha, eastern Canada and (2) the Lode assemblage (ca. $390 \mathrm{Ma}$ ), Straupe, Latvia] with a closer look at the Escuminac assemblage. Both localities are representative of Middle to Late Devonian aquatic vertebrate assemblages in terms of taxonomic richness ( $c a .20$ species), phylogenetic diversity (all major groups of lower vertebrates) and palaeoenvironment (palaeoestuaries). Fossil food web structures were assessed using different kinds of direct (i.e. digestive contents and bite marks in fossils) and indirect (e.g. ecomorphological measurements, stratigraphic species co-occurrences) indicators. First, the relationships between predator and prey body size established for the Escuminac fishes are comparable to those of recent aquatic ecosystems, highlighting a consistency of aquatic food web structure across geological time. Second, non-metric dimensional scaling on ecomorphological variables and cluster analysis showed a common pattern of functional groups for both fish assemblages; top predators, predators, primary and secondary consumers were identified. We conclude that Devonian communities were organized in multiple trophic levels and that size-based feeding interactions were established early in vertebrate history. $\bullet$ Key words: digestive contents, fossil fish, Devonian, ecomorphology, palaeoecology, bottom-up control, top-down control.
\end{abstract}

CHEVRINAIS, M., JACQUET, C. \& ClOUTIER, R. 2017. Early establishment of vertebrate trophic interactions: Food web structure in Middle to Late Devonian fish assemblages with exceptional fossilization. Bulletin of Geosciences 92(4), 491-510 (8 figures, 2 tables, electronic supplementary appendix). Czech Geological Survey, Prague. ISSN 1214-1119. Manuscript received November 21, 2016; accepted in revised form April 25, 2017; published online September 22, 2017; issued December 31, 2017.

\begin{abstract}
Marion Chevrinais, Laboratoire de Paléontologie et Biologie Evolutive, Université du Québec à Rimouski, 300 Allée des Ursulines, Rimouski, Québec, G5L 3A1, Canada; \& Institut des Sciences de l'Evolution, UMR 5554, CNRS, Université Montpellier 2, Place Eugène Bataillon, 34095 Montpellier cedex 05, France; marion.chevrinais@uqar.ca - Claire Jacquet, UMR MARBEC (Marine Biodiversity, Exploitation and Conservation), Université de Montpellier, Place Eugène Bataillon - bât 24 - CC093, 34095 Montpellier cedex 05, France \& Département de Biologie, Chimie et Géographie, Université du Québec à Rimouski, 300 Allée des Ursulines, Rimouski, Québec, G5L 3A1, Canada; claire.jacquet@uqar.ca・Richard Cloutier, Laboratoire de Paléontologie et Biologie Evolutive, Universitédu Québec à Rimouski, 300 Allée des Ursulines, Rimouski, Québec, G5L 3A1, Canada; richard_cloutier@uqar.ca
\end{abstract}

The trophic structure of recent ecosystems has long been described as controlled either by lower trophic levels (bottom-up control) or by higher trophic levels (top-down control) depending on species interactions. In extant aquatic ecosystems, both bottom-up and top-down controls are recognized (McQueen et al. 1989, Menge 2000, Arreguín-Sánchez 2011). Large species are represented in the upper trophic level, but in relatively low abundance, whereas smaller and more abundant species represent lower trophic levels (Cohen et al. 1993) imply- ing that relationships between predator and prey total lengths can be estimated.

Trophic interactions in taxonomically, environmentally and temporally diverse ecosystems of the past have been reconstructed based on direct (e.g. digestive contents) and indirect (e.g. species co-occurrences) indicators such as for e.g. the Cambrian (Vannier \& Chen 2005, Dunne et al. 2008, Vannier 2012), Devonian (Lebedev 1992, Lukševičs 1992, Novitskaya 1992, Mark-Kurik 1995, Habgood et al. 2003), Permian (Sennikov 1996, Kriwet et 
al. 2008), Jurrassic (Carrano \& Velez-Juarbe 2006, Frey \& Tischlinger 2012), Triassic (Nesbitt et al. 2006), Cretaceous (Maisey 1994, Wang et al. 2005) and the Quaternary (Nenzén et al. 2014). Most of these studies rely on qualitative descriptions of assemblages. Little is known about the similarity of species functional traits related to trophic interactions between past and recent ecosystems.

The Devonian period ( $416 \pm 2.8 \mathrm{Ma}$ to $359.2 \pm 2.5 \mathrm{Ma}$; Walker et al. 2012) is commonly referred to as 'The Age of Fishes', owing to the important evolutionary radiation of most major groups of fishes. Although it is well established that major phylogenetic events in the history of vertebrates occurred in the Devonian, not much has been documented regarding the ecological structure of these fish assemblages. This study aims to determine if structured trophic interactions among fishes were already established by the Middle to Late Devonian, and if a redundant structure can be observed between Devonian fish assemblages, given that species diversification allows for the establishment of multi-trophic ecosystems (Bambach 1999, 2002) and that fossil communities could be characterized in terms of ecological variables (e.g. number of species in a guild or a functional group; Louys et al. 2012).

In order to investigate the structure of vertebrate assemblages, we studied and compared two classical Middle to Late Devonian fish assemblages: the Escuminac (Miguasha, Québec, Canada) and Lode (Straupe, Latvia) assemblages. These two assemblages are comparable because of their taxonomic (ca. 20 vertebrate species, poor invertebrate diversity), phylogenetic (presence of representatives of most major groups of early vertebrates), palaeogeographical (coastal to the Rheic Ocean in Laurasia) and palaeoenvironmental (palaeoestuaries) similarities (Schultze \& Cloutier 1996). First, trophic links among Escuminac species were registered using direct observations of digestive contents in order to make predictions about the trophic structure of the Escuminac palaeoecosystem. In extant aquatic ecosystems, the body size of a predator is positively correlated to the mean body size of its prey (Cohen et al. 1993, Woodward et al. 2005, Barnes et al. 2010, Reuman et al. 2014). In order to evaluate the trophic structure of past communities, relationships between predator and prey length are compared to the ones observed in extant fish assemblages. Second, food web structures of both Devonian assemblages were compared. Ecomorphospace comparisons of the two Devonian communities allowed us to make predictions concerning trophic similarities of phylogenetically and morphologically closely related species. Finally, three-dimensional networking is performed to visualize food web structures. This comparison leads to fundamental questions: Are body size and other morphological traits correlated with trophic level in Devonian assemblages as it is in recent assemblages? Can we expect to detect functional similarities in Late Devonian palaeoestuaries and to record stable trophic relationships in early vertebrate evolutionary history?

Institutional abbreviations. - MHNM - Musée d'Histoire Naturelle de Miguasha (Québec, Canada); MNHN - Muséum National d'Histoire Naturelle (Paris, France); AMNH - American Museum of Natural History (New York City, USA); FMNH - Field Museum of Natural History (Chicago, USA); YPMPU - Yale Peabody Museum of Natural History (New Haven, USA); ULQ - Université Laval (Québec, Canada).

\section{Material and methods}

\section{Studied fish assemblages}

The late Givetian-early Frasnian (ca. 390 Ma) Lode assemblage (Lode clay quarry, Straupe, Latvia), including 16 vertebrate species (Upeniece 2001, Zupin̄š 2008; electronic supplementary appendix - Annex I), is a Konservat-Lagerstätte (Upeniece 2011). Plant (e.g. Archeopteris spp., Svalbardia polymorpha, Platyphyllum sp.) and invertebrate (e.g. conchostracan Pseudestheria sp., eurypterid indet., ostracod indet.) species are present (Upeniece 2001, 2011; Jurina \& Raskatova 2012). The ectoparasite Monogenea has been identified on two Lode fish species (i.e. Asterolepis ornata and Lodeacanthus gaujicus; Upeniece 2011). This case is excluded from the trophic reconstruction because of the non-predation character of parasitism. The 200-m thick Lode Formation, composed of siltstone, sandstone and clay (Upeniece 2001), shows a typical estuarine sedimentation (Pontén \& Plink-Björklund 2007). Upeniece (2011) reported the presence of swallowed prey based on which a theoretical trophic network has been reconstructed.

The middle Frasnian ( $c$ a. $380 \mathrm{Ma}$ ) Escuminac assemblage (Miguasha, Québec, Canada), including 20 vertebrate species (electronic supplementary appendix - Annex I), is considered to be a Konservat- and KonzentratLagerstätte in numerous horizons (Cloutier et al. 2011, Cloutier 2013). Plant (e.g. Archeopteris spp., Barinophyton) and invertebrate (e.g. conchostracan Asmusia membranacea, Petaloscorpio bureaui) species have been recorded (Gensel \& Barnett-Lawrence 1996, Jeram 1996, Maples 1996, Wilson et al. 2005, Cloutier 2013). The 119-m thick Escuminac Formation, registering from $59.5 \mathrm{ka}$ to $2.5 \mathrm{Ma}$, represents a typical estuarine sedimentation (Cloutier et al. 1996, 2011). Throughout the formation, more than 18,000 specimens of vertebrates have been found. Predator-prey relationships have been briefly documented (Arsenault 1982, Arratia and Cloutier 1996, Janvier 1996, Cloutier et al. 2011, Cloutier 2013); new 
Table 1. Semi quantitative and qualitative variables defined from reconstructions. ${ }^{1}$ Body anterior extremity to caudal posterior extremity; ${ }^{2}$ Head anterior extremity to opercular bones or cephalic plates posterior extremity; ${ }^{3} \mathrm{Head}$ anterior extremity to orbit anterior extremity; ${ }^{4} \mathrm{Maximum}$ height without fins; ${ }^{5}$ Horizontal diameter of the orbit.

\begin{tabular}{lcccc}
\hline Classes & $\mathrm{a}$ & $\mathrm{b}$ & $\mathrm{c}$ & $\mathrm{d}$ \\
\hline Total length $^{1}$ & $0-200 \mathrm{~mm}$ & $200-500 \mathrm{~mm}$ & $500-1000 \mathrm{~mm}$ & $>1000 \mathrm{~mm}$ \\
Body shape & depressiform & « cubic & ovoid sagittiform & fusiform \\
Mandibles & absence & presence & - & - \\
Head length ${ }^{2} /$ total length & $0-15 \%$ & $15-30 \%$ & $30-40 \%$ & $>40 \%$ \\
Mouth positon & inferior & subterminal & terminal & superior \\
Eye position & dorsal & anterior & leteral & - \\
Snout length ${ }^{3} /$ head length & $0-15 \%$ & $15-30 \%$ & $30-40 \%$ & $>40 \%$ \\
Caudal fin shape & heterocercal & hypocercal & symmetrical & - \\
Caudal height/body height ${ }^{4}$ & $0-30 \%$ & $30-70 \%$ & $70-100 \%$ & $>100 \%$ \\
Unpaired fin repartition & homogeneous & posterior half & posterior third & - \\
Teeth & absence & small & big & slide \\
Eye size ${ }^{5} /$ head length & $0-10 \%$ & $10-20 \%$ & $20-30 \%$ & $>30 \%$ \\
Mouth gape opening length/ head length & $0-20 \%$ & $20-40 \%$ & $40-60 \%$ & $>60 \%$ \\
\hline
\end{tabular}

discoveries allowed us to document numerous ingested prey remains and to reconstruct the Escuminac food web.

\section{Material}

A total of 249 specimens out of the 10,658 vertebrate specimens of the MHNM collection and five specimens from various museums have been selected for their digestive contents. Specimens were observed under binoculars (MS9.5 or MZ16A). Selected specimens were examined under a SEM in search of prey remains in the amorphous organic matter found in the digestive tract.

\section{Food web of the Escuminac assemblage}

The size range of prey for a predator is derived from scatter diagrams between prey estimated total length (eTL) and predator eTL (Scharf et al. 2000, Brose et al. 2006). For each vertebrate species, a specific eTL has been taken from the literature (electronic supplementary appendix Annex II). $\log _{10}$ eTL has been used to define an optimal scaling. Four scatter diagrams have been used to describe the relationships between prey and predator $\log _{10} \mathrm{eTLs}$ for the 20 species of the Escuminac Formation, each one defined by a lower confidence degree than the subsequent one: (1) ecomorphological theory (Wootton 1992), (2) simple stratigraphic species co-occurrences, (3) weighted stratigraphic species co-occurrences, and (4) fossilized digestive contents.

Regression 1 shows the theoretical relationship between predator $\log _{10} \mathrm{eTL}$ and their corresponding prey $\log _{10} \mathrm{eTLs}$, assuming that a predator species only feeds on smaller species (Yodzis \& Innes 1992, Cohen et al. 1993, Wainwright \& Richard 1995, Clifton \& Motta 1998). For both prey and predator species, the maximum body size is used based on data from Cloutier et al. (2009). Regressions 2 and 3 show theoretical predator-prey size relationships considering their stratigraphic co-occurrences because a predator eats prey that is temporally and spatially close (Wainwright \& Richard 1995). Only predator-prey interactions (represented in the regression 1) were included for which its stratigraphic co-occurrence (i.e. species found in the same stratigraphic horizon) was confirmed. Furthermore, each predator-prey interaction of regression 3 was weighted by the number of times the predator and its prey co-occurred in the same stratigraphic horizon. Species occurrences by stratigraphic horizon throughout the Escuminac Formation have been recorded by Cloutier et al. (2011). The two Diplacanthus species have been pooled at a generic level because of the low number of specimens and the poor stratigraphic data available on some of these specimens. Furthermore, stratigraphic data are lacking for Callistiopterus clappi and Holoptychius jarviki. A $\rho$ index $[\rho=\log (\mathrm{pij} / \mathrm{Pij})]$ frequency histogram has been plotted to show the difference between observed co-occurrence probabilities and expected co-occurrence probabilities (electronic supplementary appendix - Annex VI) (Cazelles et al. 2016). Regression 4 is performed based on the observed digestive contents for 14 species. The eTL of prey and predators were measured directly on specimens whenever possible; when direct measurement was impossible, eTL was calculated based on known proportions from reconstructions. Maximum size of Asmusia membranacea was measured on specimens when it was possible; otherwise we used the average size [i.e. $3 \mathrm{~mm}$ (Martens 1996)]. Normality (Shapiro-Wilk test; Shapiro \& Wilk 1965), 
homoscedasticity (Breusch-Pagan test; Breusch \& Pagan 1979), and residual independence (Durbin-Watson test; Durbin \& Watson 1971) were tested. Linear regressions were performed with $\mathrm{R}^{\circledR}$ software.

\section{Ecomorphological comparison of faunal assemblages}

Ecomorphological theory assumes that morphological variables are significantly correlated with foraging behaviour (Wootton 1992). Morphological disparity among the 20 Escuminac and 16 Lode vertebrate species is too important to define a common set of morphometric parameters. Owing to the broad phylogenetic representativeness, numerous structures (e.g. teeth, jaw, fins) are only present in subsets of the 36 taxa. Each taxon is defined from morphological and morphometric parameters (Willis et al. 2005). A non-metric multidimensional scaling (NMDS) was used on six semi-quantitative and seven qualitative variables observable on all taxa (Table 1) in order to attribute a trophic level to a species (Lund et al. 2014). For each variable, four classes were recognized, representing a benthophageous (class a) to pelagic predator gradient (class d) (Table 1).

NMDS quantitative data were recorded from the most recent species reconstructions because of the potential bias owing to taphonomic alteration. In addition, coding for anatomically incomplete species was estimated from closely-related species with similar complete morphology (e.g. Eusthenopteron kurshi estimated from Eusthenopteron foordi; electronic supplementary appendix - Annex II). The variable eTL is used as a proxy of body size (Cohen et al. 1993, Jennings et al. 2001, Emmerson \& Raffaelli 2004, Romanuk et al. 2010). Mouth position, size, shape, dentition, protrusion degree and eye size are indicators of diet (Clifton \& Motta 1998). For example, big eyes and mouth with teeth are traits related to predator species (Wootton 1992). Since locomotion is an important factor for predation behaviour, caudal fin shape and repartition of median fins are used as indicators of locomotion mode (Trewin 1985, Belles-Isles 1992).

The NMDS performed in Euclidean distances allowed us to associate taxa by their ecomorphological similarities. Two living taxa were included in the analysis in order to polarize the results along a benthophageous (a Rajidae) pelagic predator (Albula vulpes) gradient. A generalised skate (Batoidea, Rajidae), showing specific benthic life characters (e.g. body dorsoventrally flattened, eyes in dor- sal position) was used as representative of a benthophageous-type (Schultze 1999), whereas the bonefish Albula vulpes (Actinopterygii, Albuliformes) was used for its predator characteristics (e.g. fusiform body, eyes in lateral position, symmetrical caudal fin). Convex hulls are used to visualize species repartition and superimposition of both Devonian assemblages. An UPGMA cluster analysis using Euclidean distances (Legendre \& Legendre 1979) was performed in order to highlight clusters sharing high ecomorphological similarity. Interpretation of trophic and level classes was inferred from various sources (Dineley 1999a, b; Elliott et al. 2002; Upeniece 2011; Cloutier 2013). NMDS and cluster analysis were carried out using the software PAST $^{\circledR}$ (Hammer et al. 2001).

\section{Three-dimensional trophic networks}

Trophic interactions for the Escuminac (observed) and Lode (inferred) assemblages were modelled with Network $3 \mathrm{D}^{\circledR}$ software to visualize trophic levels of species and prey-predator interactions.

\section{Results}

\section{Food web of the Escuminac assemblage}

Digestive contents observed in 255 specimens were used to reconstruct the Escuminac food web (electronic supplementary appendix - Annex IV). Among the 255 specimens, $78(31 \%)$ showed recognizable digestive contents, and $177(69 \%)$ contained amorphous organic matter. Digestive contents have been recorded for 16 of the 20 vertebrate species.

The digestive contents of anaspids, osteostracans, placoderms, acanthodians and dipnoiforms include solely the conchostracan A. membranacea. Cheirolepis canadensis and E. foordi are the only species with vertebrates in their digestive tract (Table 2). The majority of specimens documents interactions between two trophic levels with the exception of two specimens documenting three trophic levels. The three represented levels are: primary consumers (A. membranacea), secondary consumers (Homalacanthus concinnus) and predators (C. canadensis) (MHNM 05-226 - Fig. 1; MHNM 05-399 - Fig. 2C, D); $C$. canadensis swallowed $H$. concinnus head first.

Eusthenopteron foordi is the most common species

Figure 1. Three trophic levels-specimen. $\bullet \mathrm{A}$-schematic representation of three trophic levels-specimen. Estimated length of Cheirolepis canadensis is $548.4 \mathrm{~mm}$; estimated length of Homalacanthus concinnus is $249.3 \mathrm{~mm}$. The frame indicates the region represented in the fossil B, C. $\bullet$ B - dorso-ventrally preserved specimen MHNM 05-226. $\bullet$ C - drawing of specimen MHNM 05-226. 
A
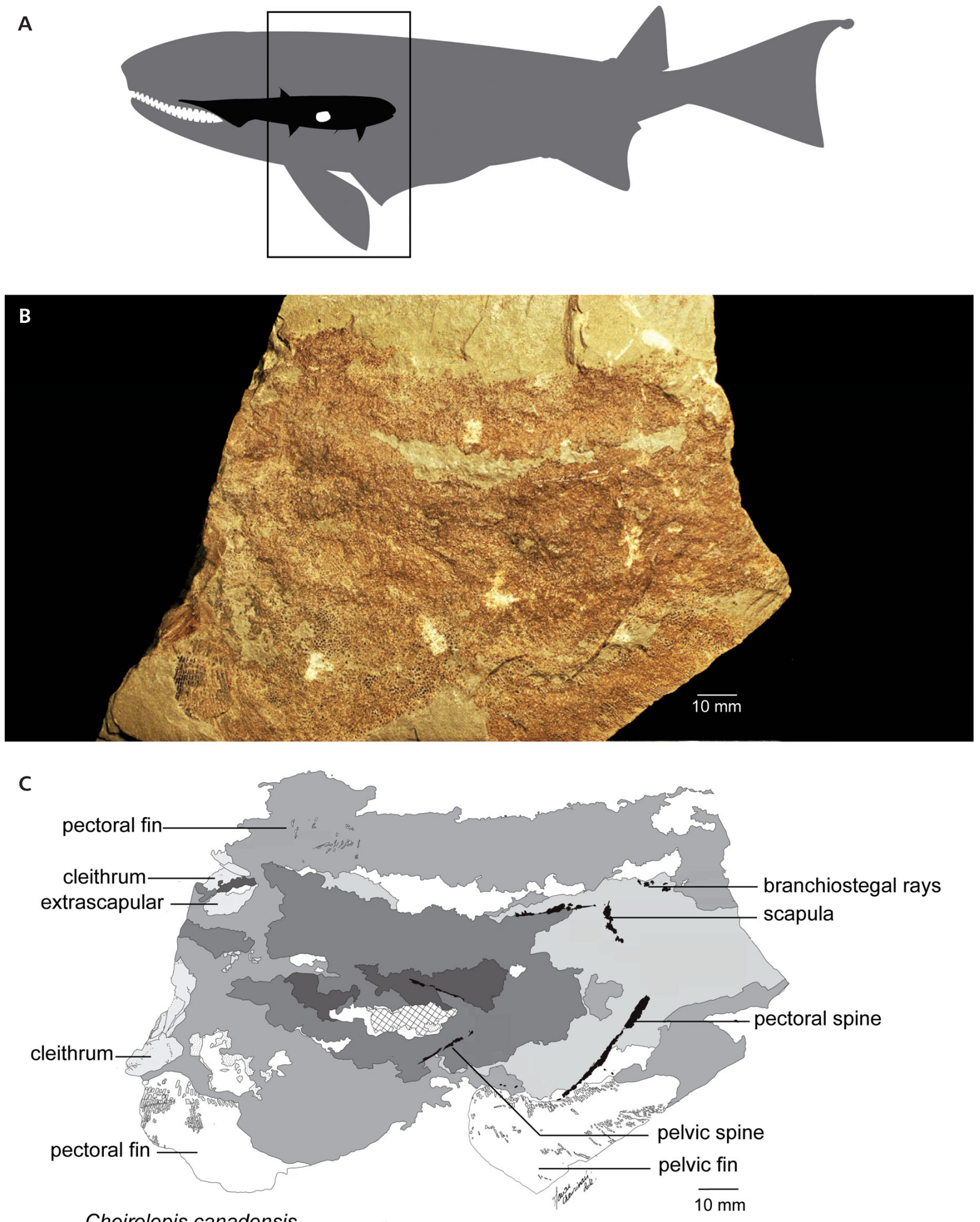

Cheirolepis canadensis

$\square$ bones $\square$ scales internal view $\square$ scales external view amorphous organic matter Homalacanthus concinnus

$\square$ bones $\square$ scales internal view $\square$ scales external view A. membranacea 
Table 2. Records of vertebrate digestive contents and corresponding stratigraphical co-occurrence probabilities (SCOP) between predator and prey species.

\begin{tabular}{lllc}
\hline Predator species & Specimen ID & Prey species & SCOP (\%) \\
\hline Cheirolepis canadensis & $\begin{array}{l}\text { MHNM 05-18 } \\
\text { MHNM 05-399 }\end{array}$ & Homalacanthus concinnus & 10 \\
Eusthenopteron foordi & $\begin{array}{l}\text { MHNM 06-700 } \\
\text { MHNM 06-915 }\end{array}$ & Bothriolepis canadensis & 0.1 \\
Eusthenopteron foordi & MHNM 06-126 & Homalacanthus concinnus & 2.9 \\
Eusthenopteron foordi & MHNM 06-32 & Cheirolepis canadensis & 1.8 \\
& AMNH 5968 & & \\
Eusthenopteron foordi & MHNM 06-1754 & Scaumenacia curta & 9.5 \\
\hline
\end{tabular}

with fish found in the digestive tract. A total of 66 specimens of $E$. foordi demonstrated digestive contents; prey have been identified in 24 of these specimens (36\%). Two specimens of E. foordi showed a specimen of Bothriolepis canadensis in the anterior part of the digestive tract (Fig. 3A, B); in both specimens, the ingested specimens of $B$. canadensis were relatively medium-sized individuals (eTL $=96 \mathrm{~mm}$ and $139 \mathrm{~mm}$, electronic supplementary material Annex VII) with pectoral fins, cephalic and thoracic plates preserved. In most cases of predation by $E$. foordi, prey [H. concinnus (Fig. 3C), C. canadensis (Fig. 4A), $S$. curta (Fig. 4B)] were swallowed head first. The predatory behaviour of $E$. foordi was present early in ontogeny: a complete juvenile specimen of $E$. foordi $(\mathrm{eTL}=58 \mathrm{~mm})$ has ingested a complete juvenile specimen of Scaumenacia curta (eTL $=36 \mathrm{~mm}$ ) (Fig. 4B; Béchard, personal communication).

For the predators C. canadensis (MNHN 1968.8.4 Fig. 2A, B) and E. foordi (MHNM 06-502, FMNH PF6261 - Fig. 4C, D), we found evidence for cannibalistic behaviour. Prey size did not exceed $70 \%$ of E. foordi body size (electronic supplementary appendix - Annex VIII) with the exception of the extreme value of $86 \%$ in specimen FMNH PF6261. C. canadensis consumed prey in a body size range of 45 to $70 \%$ of its eTL (electronic supplementary appendix - Annex VIII). In E. foordi specimen FMNH PF6261 (Fig. 4D) as well as $C$. canadensis specimens MNHN 1968.8 and MHNM 05-399 (Fig. 2 B), the caudal fin of the prey is still in the oral cavity of the predator; the attempt to swallow the prey likely caused the suffocation of the predator.

The three relationships between prey maximum body size and predator maximum body size for the Escuminac assemblage are characterized by similar equations: (1) theoretical (Fig. 5A): $\log 10$ prey body size $=0.9769 \times\left(\log _{10}\right.$ predator body size $)-0.5075\left(P=6.114 \times 10^{-10} ; \mathrm{R}^{2}=\right.$ 0.173); (2) simple co-occurrences (Fig. 5B): prey $\log _{10} \mathrm{eTL}=1.4195 \times\left(\right.$ predator $\left.\log _{10} \mathrm{eTL}\right)-0.1318(P=$ $\left.2.78 \times 10^{-5} ; \mathrm{R}^{2}=0.1729\right)$; and (3) weighted co-occurrences (Fig. 5C): prey $\log _{10} \mathrm{eTL}=1.2411 \times\left(\right.$ predator $\left.\log _{10} \mathrm{eTL}\right)-$ $1.7077\left(P<2.2 \times 10^{-16} ; \mathrm{R}^{2}=0.1511\right)$.

We used data of actual co-occurrences of species to calculate the probabilities of co-occurrence of species show- ing likelihood of species association (electronic supplementary appendix - Annex V). A highly correlated correspondence occurs between maximum co-occurrence probabilities (pij) and observed co-occurrence probabilities $(P \mathrm{ij})\left(r=0.95 ; P<2.2 \times 10^{-16}\right)$. Because the linear regression of $\mathrm{Pij} \times$ pij is higher than the $1: 1$ relation, it implies that observed co-occurrence probabilities $(P \mathrm{ij})$ are higher than expected co-occurrence probabilities (pij) (electronic supplementary appendix - Annex VI).

Using digestive contents, regression 4 (Fig. 5D) shows a relationship between predator estimated maximum total length and prey estimated maximum total length: prey $\log _{10} \mathrm{eTL}=0.8434 \times$ (predator $\left.\log _{10} \mathrm{eTL}\right)-1.28(P=$ $\left.4.657 \times 10^{-4} ; \mathrm{R}^{2}=0.1535\right)$. This linear regression required estimated size for incomplete fossil specimens (electronic supplementary appendix - Annex VII). In some species, the estimated size using morphological proxies is higher than the previously recorded maximum size (Cloutier et al. 2009). Asmusia membranacea estimated sizes are often smaller than those estimated by Martens (1996); it is likely due to differences in age.

\section{Ecomorphological comparison of faunal assemblages}

The NMDS shows similar patterns of species distribution in both assemblages (Fig. 6). The ecomorphospace of both assemblages is similar and overlaps extensively. A $17 \%$ stress index is indicative of a weak deformation of raw values. The NMDS shows trophic network clustering. The UPGMA (Fig. 7) specifies the clustering observed with the NMDS. Trophic clusters have been defined by combining NMDS and UPGMA results.

The benthophageous cluster (secondary consumers), associated with the Rajidae, gathers placoderms (i.e. B. canadensis, Asterolepis ornata), osteostracans (i.e. Escuminaspis laticeps, Levesquaspis patteni) and heterostracans (i.e. Psammolepis spp.). They forage essentially on invertebrate species (i.e. A. membranacea, primary consumers). Secondary pelagic consumers include acanthodians (Homalacanthus concinnus, Diplacanthus spp., Triazeugacanthus affinis, Lodeacanthus gaujicus), 

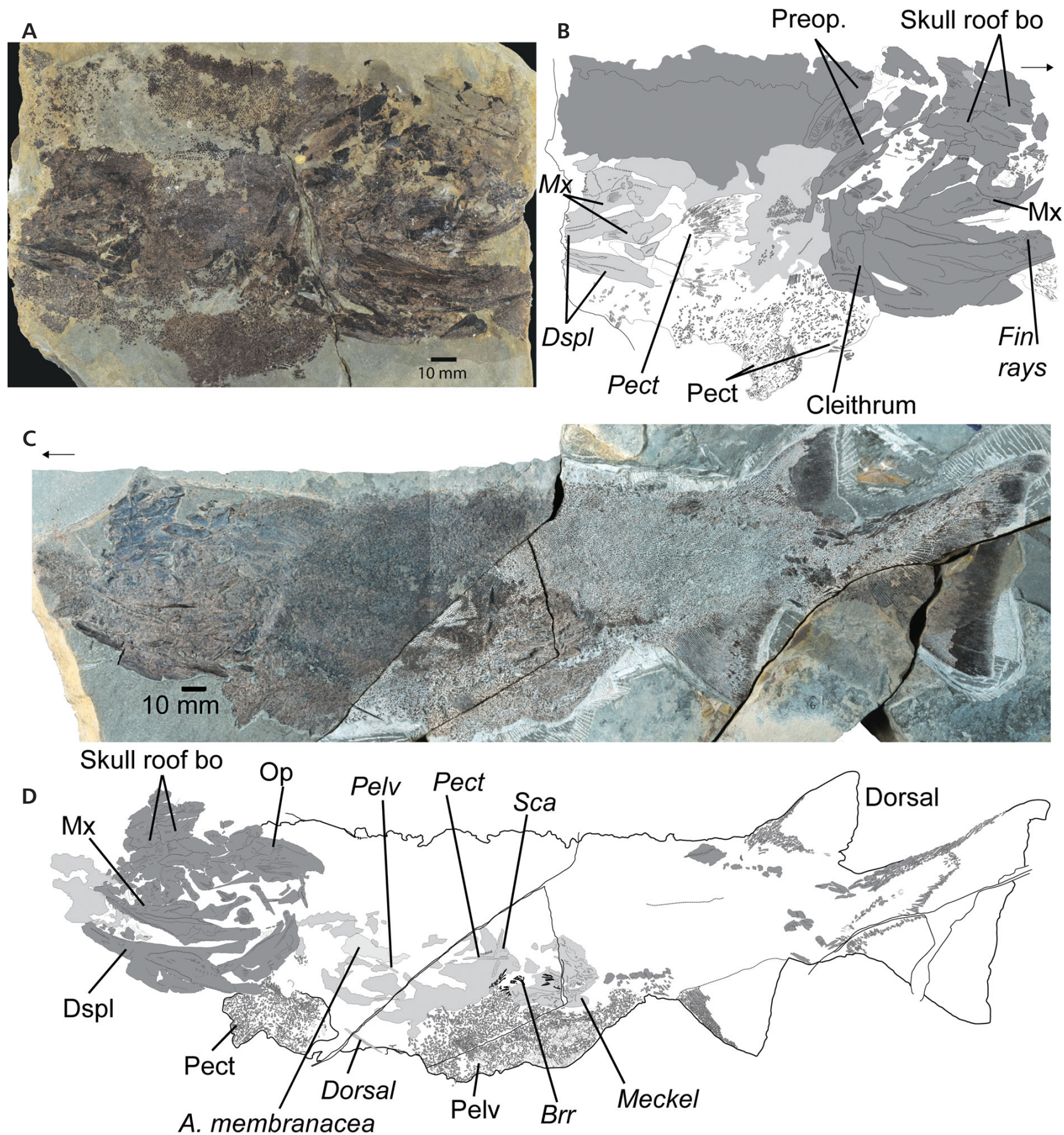

Figure 2. Digestive contents of the actinopterygian Cheirolepis canadensis. • A - photography and B - drawing of specimen MNHN 1968.4 with a swallowed C. canadensis skull roof bones (Skull roof bo), preopercular (Preop.), maxillary (Mx), pectoral fins (Pect), cleithrum and dentalospenial. - C - photography and D - drawing of a swallowed Homalacanthus concinnus with Asmusia membranacea in his digestive tract MHNM 05-399 showing skull roof bones (Skull roof bo), maxillary (Mx), opercular (Op), dentalospenial (Dspl), pectoral fins (Pect) and pelvic fins (Pelv), scapulocoracoid (Sca), branchiostegal rays (Brr), Meckel's cartilage (Meckel). Regular text is for the predator skeletal elements, italic text is for the prey skeletal elements. Arrow points anteriorly.

anaspids (Euphanerops longaevus, Endeiolepis aneri) and also the onychodont Strunius sp.

Two clusters composed of pelagic species correspond to predators and top predators. Predators are gathered around Albula vulpes. This cluster includes piscivores such as "osteolepiforms" (Eusthenopteron spp., Osteolepididae), porolepiforms (Glyptolepis baltica, Laccognathus panderi, Holoptychius jarviki, Holoptychidae indet.), 
actinistians (Miguashaia spp.), and a dipnoiform (Scaumenacia curta). An additional predator cluster includes the actinopterygian Cheirolepis spp. and the juvenile "osteolepiform" Callistiopterus clappi. Top predators are the elpistostegalian Elpistostege watsoni and Panderichthys rhombolepis. An intermediate cluster, occurring in the centre of the NMDS distribution, shows Plourdosteus canadensis and Fleurantia denticulata. UPGMA allowed us to gather Plourdosteus canadensis with predator species and Fleurantia denticulata with secondary consumers; these two taxa represent deepest rooted branches for large predators and secondary consumers, respectively. Phylogenetically related species (En. aneri and Eup. longaevus; El. watsoni and P. rhombolepis; Es. laticeps and L. patteni; M. bureaui and M. grossi; En. aneri and Eup. longaevus; E. foordi and E. kurshi; El. watsoni and $P$. rhombolepis) show high bootstrap values (67 to 96\%) (Fig. 7). Lower bootstrap values correspond to larger trophic clusters such as secondary consumers and predators (40\%) and benthophageous forms (45\%).

\section{Three-dimensional trophic network}

Three-dimensional visualization of Lode and Escuminac food webs (Fig. 8) highlights food web structures with up to four trophic levels. The Lode ecosystem shows a lack of links between the Miguashaia grossi ending arm and the top predators (i.e. P. rhombolepis, La. panderi, G. baltica) ending arm. However, these taxa most likely foraged on the same species.

Concerning the Escuminac assemblage (Fig. 8B), primary and secondary consumers are well-represented in the digestive model, whereas predators are poorly represented. More specifically, E. foordi shows the highest trophic level followed by $C$. canadensis. In terms of trophic interactions, the comparison of these two palaeoecosystems revealed new insights into the ecological dynamics and interspecies relationships during the Middle to Late Devonian.

\section{Discussion}

The reconstruction of the Escuminac and Lode food webs demonstrates similar structures suggesting that vertebrate trophic interactions were already established by the Middle Devonian in estuarine environments. The trophic structure of the Miguasha Fossil-Fish-Lagerstätte corresponds to one of the oldest vertebrate trophic assemblage showing interactions across three trophic level, two cannibalistic species and predation among juveniles. The Escuminac food web has been investigated based on exhaustive primary data, while the Lode food web was reconstructed primarily from the literature (Upeniece 2011) and our ecomorphological analysis. In the following discussion on the Middle to Late Devonian fish assemblages, we will address three points: (1) are the primary palaeobiological data reliable and informative about the actual palaeoecological interactions? (2) how can gut contents inform us about the role and ecological niche of species? and (3) how can trophic interactions inform us about the ecological persistence of ecosystems in deep time (i.e. similarities between past and present food webs)?

\section{Trophic interactions within the Escuminac assemblage}

The Escuminac Formation is characterized by the exceptional preservation of a large part of its fauna (Cloutier $2010,2013)$. The studied sample size ( $N=78$ with identifiable gut content) used to reconstruct the food web is large enough to be considered reliable. In addition, we consider the Escuminac taphonomic assemblage as a biological community (sensu Lebedev 1992) because the transportation of fish carcasses was limited or absent (Parent \& Cloutier 1996, Cloutier et al. 2011). This assumption implies that species found in association came from the same habitat. Furthermore, digestive contents are considered as direct evidence of what the fish were eating at the time of death (Boucot 1990, Maisey 1994) and thus correspond to frozen behaviour (Maisey 1994). We therefore consider that our interpretation of the Escuminac food web structures is a reliable approximation to the actual Devonian food web.

Although numerous Escuminac specimens were found with identifiable digestive contents, the proportion of predators with fish prey remains relatively low compared to the number of specimens with solely amorphous organic matter or devoid of digestive contents. Among living freshwater and marine top predator fishes, numerous stomach

Figure 3. Digestive contents of the osteolepiform Eusthenopteron foordi. • A - photography and D - drawing of a swallowed Bothriolepis canadensis MHNM 06-915 showing antero-ventral plate (AVL), posterior oblique abdominal pitline groove (Dlg2), radius (Rad), ulna (Ul), ulnare (Uln), pectoral fin bones (I-V). • B - photography and E-drawing of a swallowed B. canadensis MHNM 06-700 showing clavicle (Cla), cleithrum (Clm), intercentrum (Ic), infradentary (Id), neural arch (Na), pelvic scutes (Pelv Scu), sub-mandibular (Sbm) and sub-opercular (SOp). $\bullet$ C - photography and F - drawing of a swallowed Homalacanthus concinnus MHNM 06-126 showing branchiostegal rays (Brr), cleithrum (Clm), entopterygoid (Entp), gular (Gu), opercular (Op), pre-articular (Part), pectoral fin spine (Pect), pelvic fin spine (Pelv), quadratojugal (Qj), scapulocoracoid (Sca), squamosal (Sq), subopercular (SOp). Regular text is for the predator skeletal elements, italic text is for the prey skeletal elements. Scale bars equal $10 \mathrm{~mm}$. 
Marion Chevrinais et al. - Early establishment of vertebrate trophic interactions: Food web structure

A
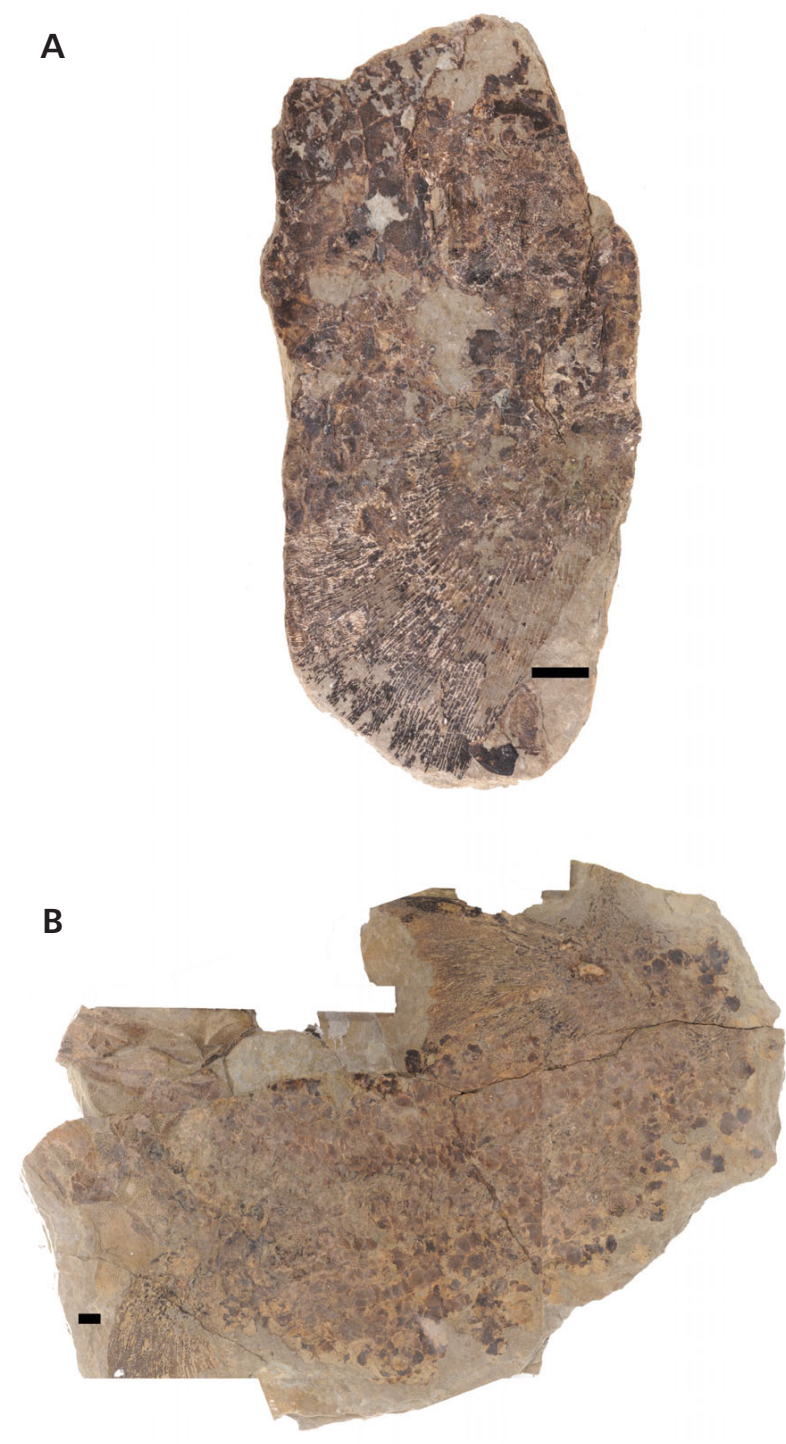

C

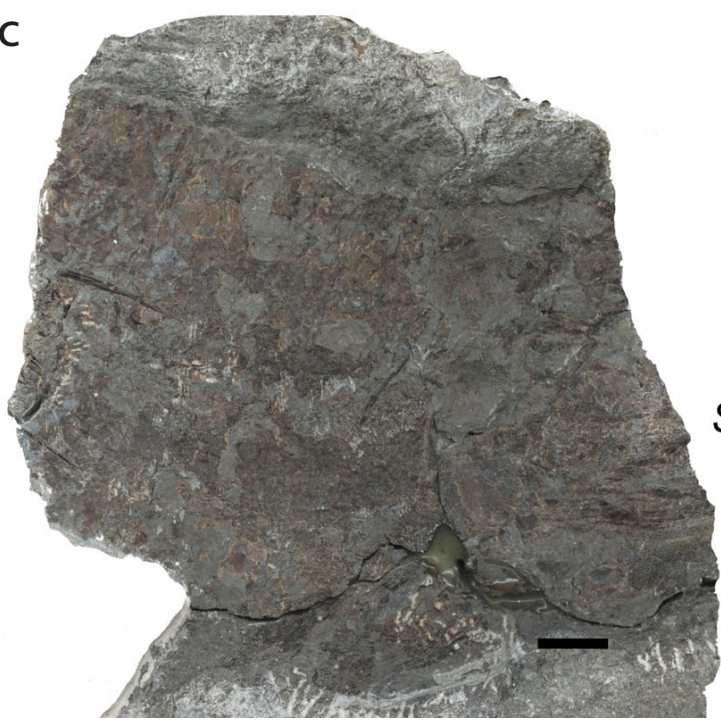

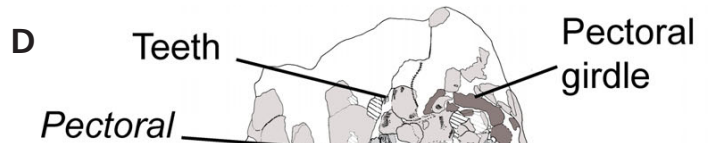
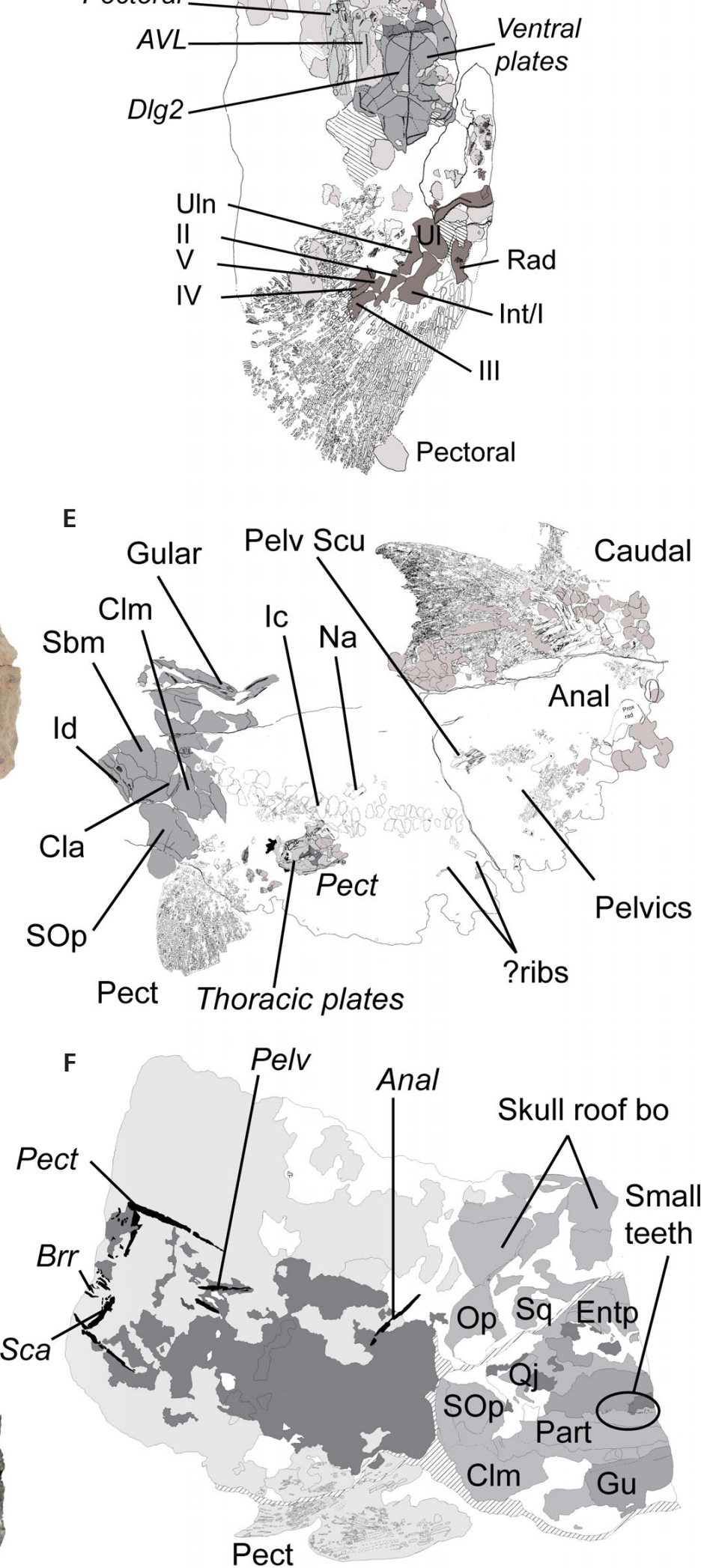
content analyses also indicate a fairly high proportion of fish with empty stomach: Esox lucius: 222 empty out of 409 (54\%; Alp et al. 2008); Albula vulpes: 67 empty out of 385 (17\%; Crabtree et al. 1998); Thunnus maccoyii: 453 empty out of 1997 (23\%; Itoh \& Sakai 2016). In living species, the proportion of predators with empty stomach could vary as a result of various causes such as prey availability, seasonal feeding behaviour, ontogenetic diet shift, fasting during spawning and/or migration and health condition. In addition to these potential causes, the preservation of stomach content in fossil fish could be subjected to different taphonomic conditions such as fermentation from the gut flora or reduced $\mathrm{pH}$ of the gut. Thus, the amorphous organic matter observed in numerous specimens might either correspond to the infilling of the digestive tract, a post-mortem decay of the digestive content or the soft tissues of the digestive organs themselves. However, preliminary analyses in SEM of the amorphous organic matter did not provide evidence for the presence of phytoplankton, zooplankton, nor decayed carcasses of fishes. The dark colour and the anatomical position of the amorphous organic matter show similarities with the preservation of "internal organs" interpreted by Davidson \& Trewin (2005) either as liver, spleen, kidney or gut in various acanthodians, actinopterygians and placoderms from the Middle Devonian Tynet Burn and Gamrie localities in Scotland.

The analysis of digestive contents allowed us not only to reconstruct the food web and to record two trophic links (C. canadensis-H. concinnus and H. concinnus-A. membranacea) but also to highlight a three-trophic-level chain (Figs 1; 2C, D). This kind of evidence is very rare given the quality of preservation needed (Kriwet et al. 2008, Frey \& Tischlinger 2012). The three represented levels are: primary consumers (A. membranacea), secondary consumers (H. concinnus) and predators ( $C$. canadensis). The excellent state of preservation suggests that $H$. concinnus has been swallowed shortly after its last feed.

In the Escuminac assemblage, the general scheme of the linear relationship between predator and prey total length shows a triangular structure. Range and mean of prey size (eTL) increase with predator size (eTL). This relationship in Devonian species is typical of the relationships observed in extant aquatic food webs (Cohen et al. 1993, Scharf et al. 2000).

Co-occurrence data are indicative in terms of probabilities for species to share the same habitats. The relationship between stratigraphic species co-occurrence probabilities and the observed digestive contents suggests a strong reliability for the observed data from Escuminac fossils (electronic supplementary appendix - Annex VI).

The bottom part of the Escuminac trophic network is poorly understood owing to the rarity of macro- and microinvertebrates. Algae are assumed to have been the aquatic primary producers of the Escuminac assemblage (Cloutier 2013) although their presence in palynofacies is fairly rare (Cloutier et al. 1996). Escuminac aquatic primary consumers are polychaetes (although only a single scolecodont has been found according to Cloutier et al. 1996), eurypterids (i.e. parastylonurid, Pterygotus; Jeram 1996) and some soft-bodied organisms known solely from ichnofossils (e.g. Planolites, Gyrophyllites; Maples 1996). Each of these taxa is exceedingly rare in the Escuminac Formation in spite of the exhaustive sampling. Thus, the Escuminac trophic assemblage is peculiar because it is based on only one abundant and ubiquitous aquatic invertebrate species, the conchostracan A. membranacea (Cloutier et al. 2011). In modern aquatic ecosystems, benthic invertebrates are responsible for the transformation of organic detritus into dissolved nutrients to enhance primary production (Covich et al. 1999), as a result they play a prevailing role in the ecosystem because the energy of all higher level species runs through them (Dunne 2009). In the Escuminac assemblage, A. membranacea has been recorded in all fish species with identifiable digestive contents and possibly was a bottom-up control on the ecosystem; however, the prevalence of this species was due either to the true absence of other primary consumers or to a poor fossilization of other invertebrate primary consumers (taphonomic bias). Poor fossilization of soft bodied animal could be a potential bias, but the rarity of ichnofossils and bioturbation corroborates a poor diversity of primary consumers. Recent conchostracans (e.g. Cyzicus) are not constrained to particular habitats; they are found in the benthos as well as in the plankton (Popović \& Gottstein-Matočec 2006). By analogy with living conchostracans, Escuminac species found with $A$. membranacea are not attributable to a distinct habitat based solely on the presence of this prey item; however, certain species have been found preferably associated with certain facies or stratigraphic horizons (Cloutier et al. 2011). Top predation contributes to the stability of a trophic network by means of uninterrupted predator action on prey. The top part of the Escuminac trophic network is occupied by the osteolepiform E. foordi, a generalist predator. Eusthenopteron foordi was piscivorous

Figure 4. Digestive contents of the osteolepiform Eusthenopteron foordi. • A - photography and E - drawing a swallowed Cheirolepis canadensis MHNM 06-32 showing proximal radial of anal fin (A Prad), clavicle (Cla), caudal neural arch (C Na), caudal ventral radial (C vtl rad), scutes of first dorsal fin (D1 cu), proximal radial of second dorsal fin (D2 Prad), radials of second dorsal fin (D2 rad), entopterygoid (Enpt), haemal arch (Ha), jugal (Ju), maxillary (Mx), possible pectoral and pelvic lepidotrichia (Pect and Pelvic lepi?), premaxillary (Pmx), pre-opercular (Pop), postorbital (Porb), vertebral element imprints (Vtl el). B - photography and F - drawing of a swallowed Scaumenacia curta MHNM 06-1754 showing cleithrum (Clm), first dorsal 

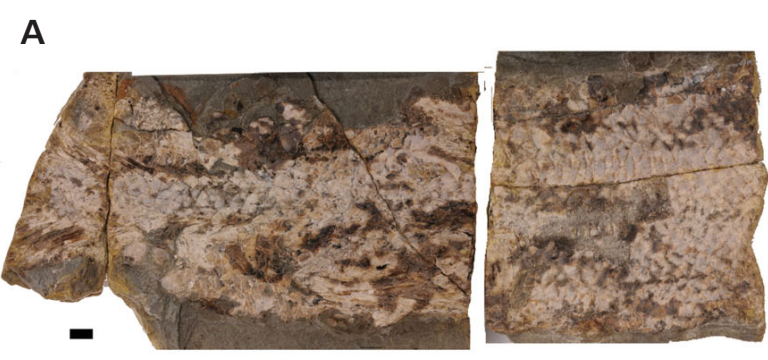

B

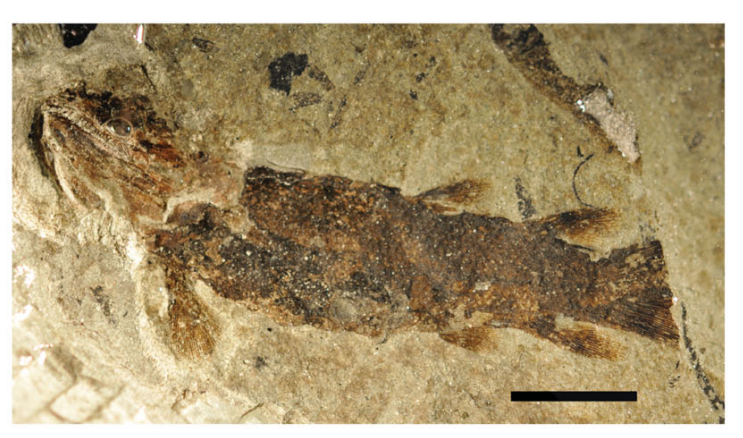

C

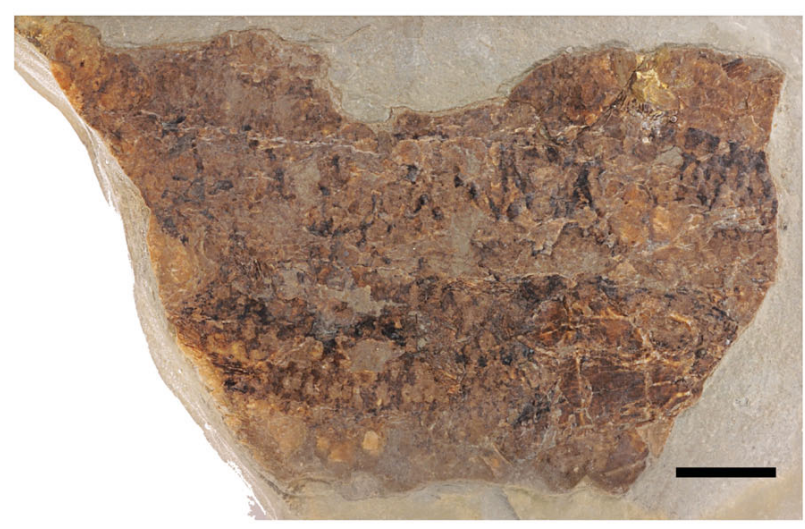

D

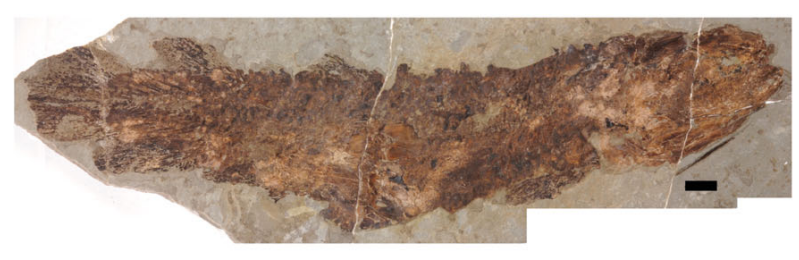

E

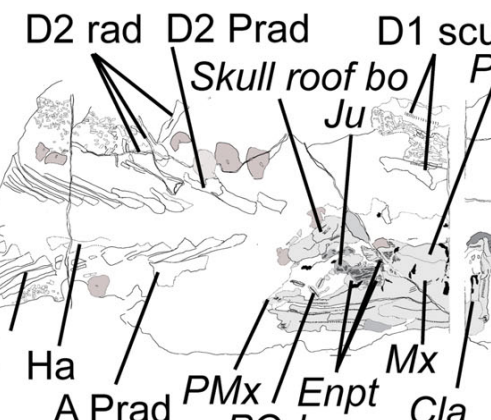

rad
A Prad PMx POrb

$\mathrm{F}$

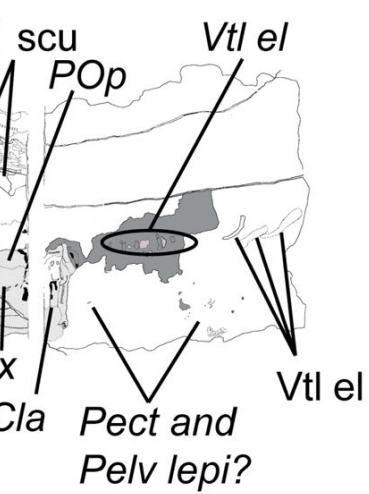

Skull roof bo $\mathrm{Mx} \mathrm{Sq}$

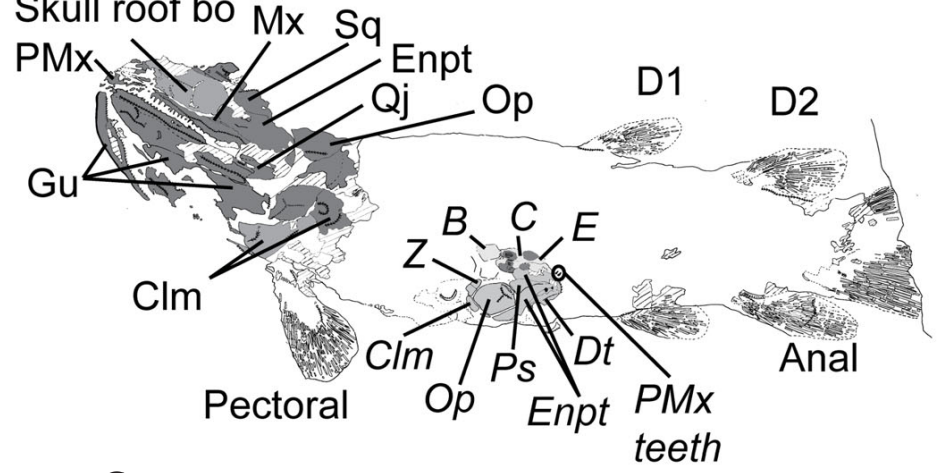

G
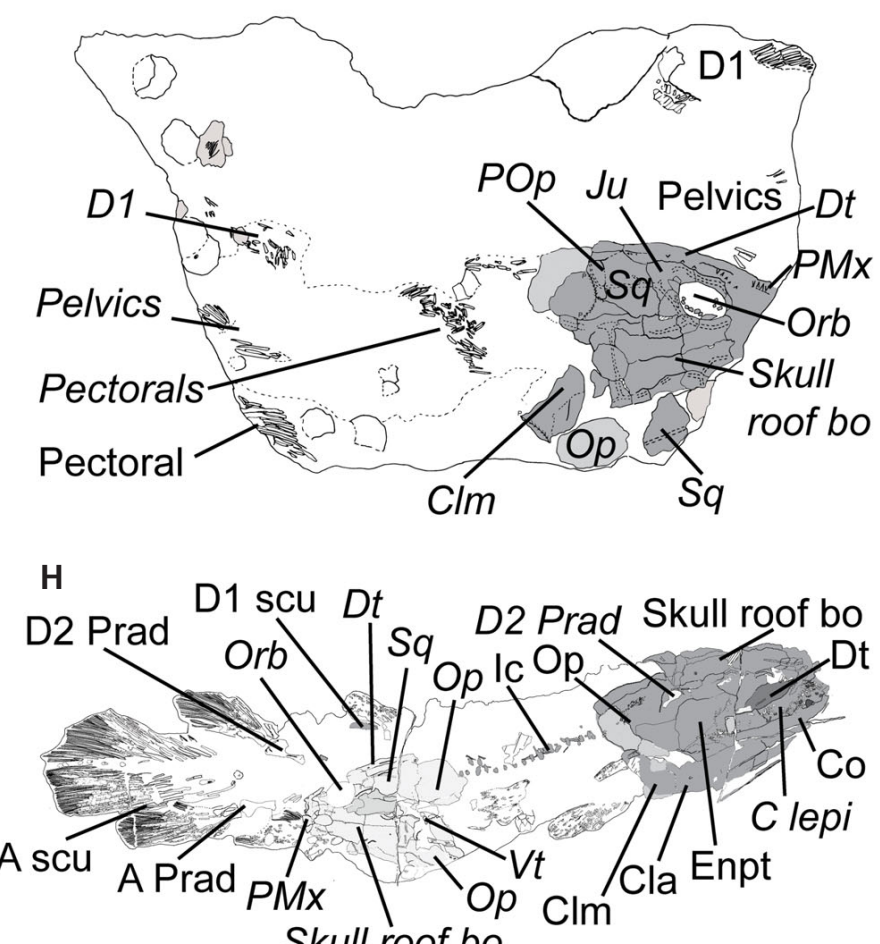

Skull roof bo

fin (D1), second dorsal fin (D2), dentary (Dt), entopterygoid (Enpt), gular (Gu), maxillary (Mx), opercular (Op), premaxillary (Pmx), parasphenoid (Ps), quadratojugal (Qj), squamosal (Sq) $\bullet$ C - photography and G - drawing of a swallowed E. foordi MHNM 06-502 showing cleithrum (Clm), dentary (Dt), first dorsal fin (D1), jugal (Ju), opercular (Op), orbit (Orb), premaxillary (Pmx), preopercular (Pop), squamosal (Sq)・ D - photography and H - drawing of a swallowed E. foordi FMNH PF6261 showing anal proximal radial (A Prad), scutes of anal fin (A scu), clavicle (Cla), cleithrum (Clm), caudal lepidotrichia (C lepi), coronoid (Co), dentary (Dt), scutes of first dorsal fin (D1 scu), proximal radial of second dorsal fin (D2 Prad), entopterygoid (Enpt), intercentrum (Ic), opercular (Op), orbit (Orb), premaxillary (Pmx), squamosal (Sq), first vertebral elements (Vt). Regular text is for predator skeletal elements, italic text is for prey skeletal elements. Scale bars equal $10 \mathrm{~mm}$. 


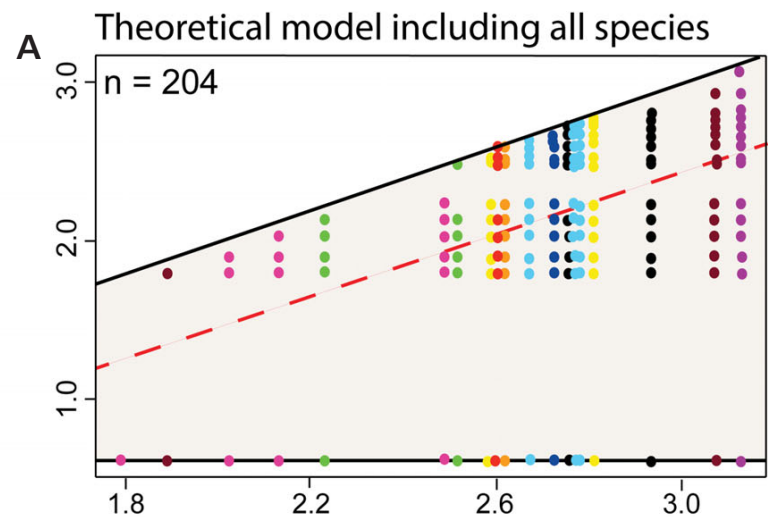

B Simple stratigraphical co-occurrences

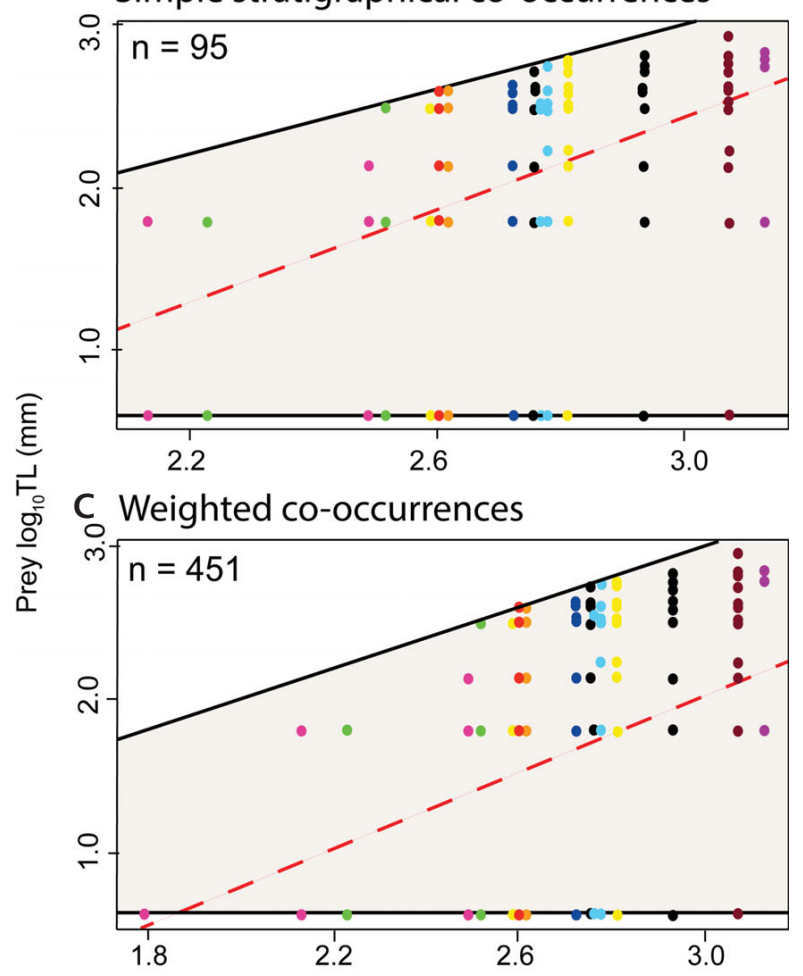

D Observed digestive contents

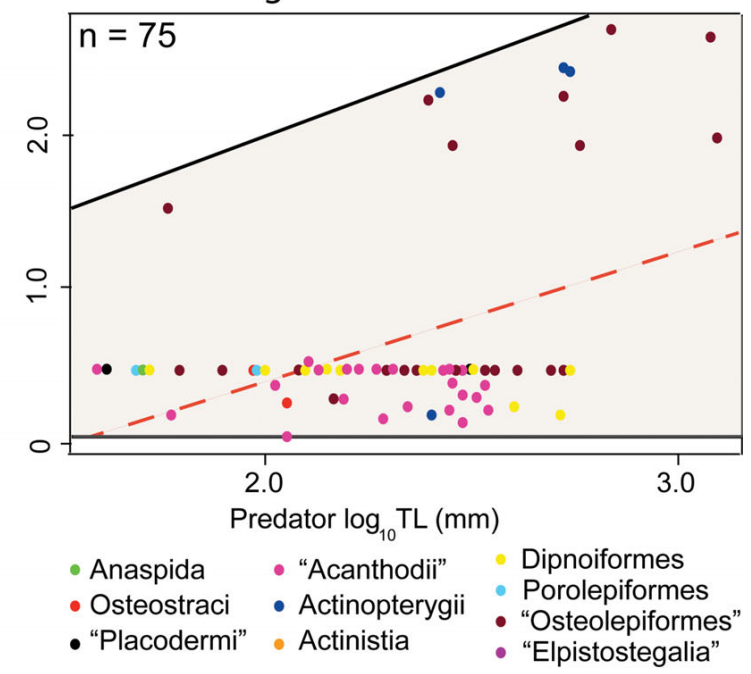

even as a juvenile and remained piscivorous throughout its life. Eusthenopteron foordi foraged on six different species: A. membranacea, $H$. concinnus, $S$. curta, C. canadensis, B. canadensis and E. foordi. The large range of prey and the lack of permanent predation on $E$. foordi allow us to consider this species as the top predator, having a top-down control on the ecosystem. The low ratios between the estimated prey size and the estimated size of E. foordi indicate that prey had to be small enough to avoid oesophageal abrasion and decrease manipulation time and escape rate (Fig. 5) (Reimchen 1991). Based on size alone, the elpistostegalian Elpistostege watsoni would have been a top predator reaching a size exceeding that of E. foordi; however, the known occurrence and the rarity of this species would suggest only sporadic incursion into the palaeoestuary.

The prevalence of E. foordi and A. membranacea shows that mechanisms for top-down and bottom-up controls were already present in Devonian ecosystems, as observed in the majority of modern aquatic ecosystems (McQueen et al. 1989, Menge 2000, Arreguín-Sánchez 2011). Changes of top predators affecting the prey fauna is a major factor causing faunal turnovers (Hunter \& Price 1992, Ripple et al. 2010, Mitchell et al. 2012), thus it appears like E. foordi contributed to the stability of this Devonian ecosystem.

\section{Interpretative palaeoecological synthesis}

Estuaries are characterized by fluctuating physicochemical conditions. Estuarine species thus have to tolerate a wide range of these conditions including fluctuations in salinity, turbidity, oxygen concentration and temperature (Able \& Fahay 2010, Schultze 2013). Estuarine ecosystems have long been recognized as an important reproductive and feeding area, especially for fishes, because of its high productivity controlled by fluctuating abiotic (e.g. temperature, turbidity, salinity) and biotic (e.g. prey availability, intra- and interspecific competition) ecological factors (Costanza et al. 1997, Peterson 2003, Nicolas et al. 2010). An interpretative palaeoecological synthesis of the Escuminac biota is proposed based on trophic level comparison and predation models.

Several features (e.g. mouth opening) and variables (e.g. total length) can be used to identify the trophic level of

Figure 5. Predator size-prey size scatter diagrams in terms of total length (TL, $\log _{10}, \mathrm{~mm}$ ) based on five parameters for the 20 species of the Escuminac assemblage. Regression line is in red. Continuous lines represent minimum and maximum prey sizes, whereas dashed line represents mean prey sizes (linear regression). $\mathrm{N}$ is for the number of points on the graph, showing supposed or observed prey-predator interactions. 

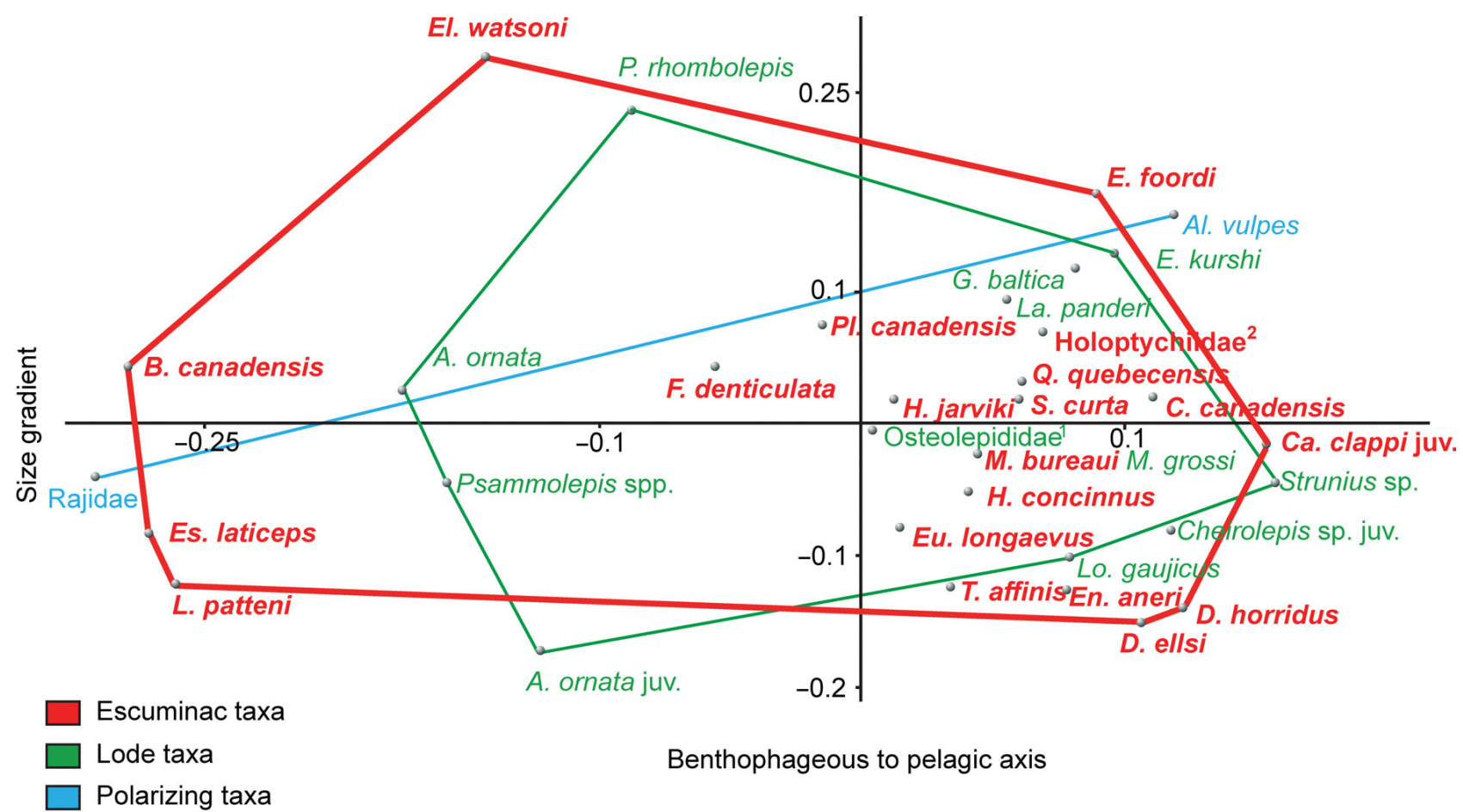

Benthophageous to pelagic axis

Figure 6. Non-metric multidimensional scaling from morphological and morphometric data scored for the Escuminac and Lode vertebrate species. ${ }^{1}$ gen. and sp. indet.; ${ }^{2}$ indet. Euclidean distances. Stress index: $17 \%$.

an organism (Wainwright \& Richard 1995, Labropoulou \& Eleftheriou 1997) even in the fossil record. High trophic levels (i.e. top predators and prey) are limited by energetic constraints, whereas low trophic levels (i.e. primary and secondary consumers) are limited by morphological constraints as mouth opening capacity (Romanuk et al. 2010). We did not use the common ratio between mouth opening length and head length as a proxy of trophic level (Clifton \& Motta 1998, Upeniece 2011) because none of the studied species were capable of jaw protrusion (Schaeffer \& Rosen 1961, Alexander 1967, Motta 1984, Westneat 2004). However, median fins clustered towards the posterior part of the body are characteristic of lurking predators (Belles-Isles 1992). In our study, actinopterygians, dipnoiforms, porolepiforms and osteolepiforms from the Escuminac and Lode Formations showed a highly similar pattern of median fin distribution; however, dipnoiforms display a morphology suggesting lurking predation although gut contents are devoid of fish prey. Such morphology is indicative of this mode of predation in the Middle Devonian porolepiform Glyptolepis from the Achanarras Fish Bed (Caithness, Scotland) and it has been compared to the living Esox (Trewin 1985). Gut contents of Glyptolepis show that prey (including Glyptolepis; Trewin 1985) was swallowed head first (Ahlberg 1992). With respect to the Escuminac fish, lurking predation had also been suggested for E. foordi (Arsenault 1982). This behaviour is further corroborated by our discoveries. Furthermore, in the digest- ive contents of E. foordi and C. canadensis, all prey have been swallowed head first. This predation mode is also described as a typical predation mode for extant piscivorous fishes (Elliott et al. 2002). Piscivores generally reorient their prey after catching it in order to swallow it head first and lying on its side (Reimchen 1991, Nilsson \& Brönmark 2000). In addition, the size proportion between prey and predator is an indicator of predation mode (Peters 1983). To qualify the prevailing predation mode, a positive relationship between prey total length and predator total length has been recorded in $C$. canadensis and E. foordi. The ratio between prey and predator total length in E. foordi $[70 \%$ (86\% max.)] and C. canadensis (45 to $70 \%$ ) is very high even when compared to the values observed in modern top predators [ $\mathrm{ca}$. $10 \%$ in Esox lucius (Nilsson \& Brönmark 2000), 20\% (33\% max.) in Thunnus obesus and 8\% (26\% max.) in T. albacores (Ménard et al. 2006)]. In a large number of cases of frozen behaviour from Escuminac, the predators have most likely suffocated by swallowing exceedingly large prey. In studies of modern ecosystems, predators have to surpass a body size threshold (avoiding suffocation) before becoming piscivorous (Able \& Fahay 2010). Prey size in E. lucius is limited by pike gape size but most importantly by prey body depth (Nilsson \& Brönmark 2000). Most likely the lurking predation mode has evolved relatively early in the evolution of gnathostomes and is most prevalent by the Middle to Late Devonian.

Intercohort cannibalism (i.e. adults foraging on larvae 


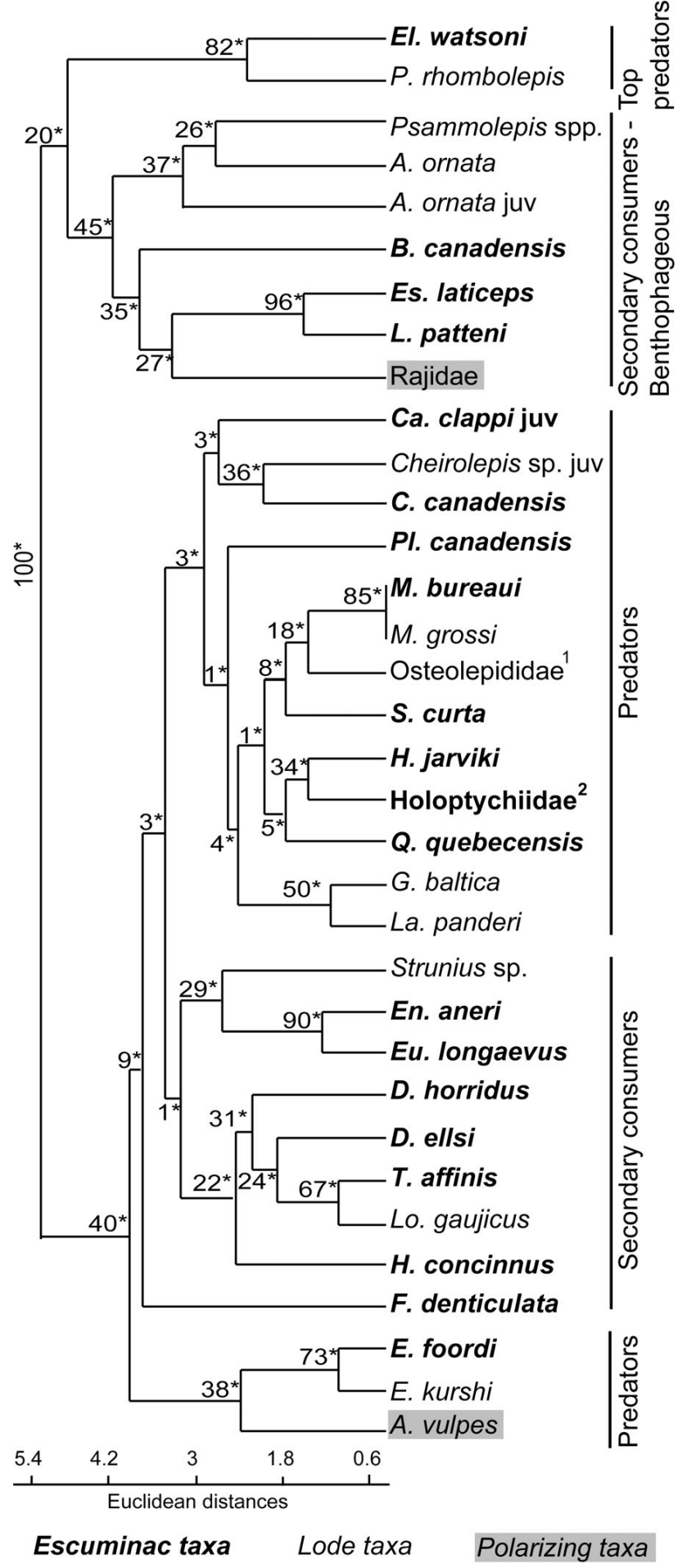

Figure 7. Cluster analysis with morphological and morphometric characters. UPGMA method and Euclidean distances. *bootstrap values for 1000 iterations; ${ }^{1}$ gen. and sp. indet.; ${ }^{2}$ indet. Correlation coefficient: $85 \%$.

or juveniles) and intracohort cannibalism (i.e. prey and predator have same size or, at least are interpreted as same development stage) are frequent in extant species (Elliott et al. 2002). Cannibalism can result from abnormal foraging behaviour and abnormal stress response (Elliott et al. 2002). However, cannibalism can also be ecologically justified and viable in a community because it provides several advantages in terms of population dynamics (Elliott $e t$ al. 2002). Ecologically, cannibalism can be interpreted as a stabilising agent in an ecosystem by (1) the reduction of organism density in a specific cohort (e.g. consumption of larvae and juveniles) (Smith \& Reay 1991) and (2) the reduction of intraspecific competition for resources when populations are characterized by high densities and/or juveniles with limited resource access. Because $E$. foordi is one of the ubiquitous species of the Escuminac assemblage (Cloutier et al. 2011), this species occurred probably in dense populations and in different habitats because it foraged on both benthophageous (B. canadensis) and pelagic (C. canadensis and H. concinnus) prey. Cannibalism could therefore be related to a specific cohort consumption in response to strong intraspecific competition. Approximated total length of prey is $24 \%$ and $65 \%$ of respective predator total length; so prey and predators could belong to several age classes in E. foordi. In C. canadensis, two specimens show cannibalism (Arratia \& Cloutier 1996; this study) with estimated prey size being $52 \%$ of estimated predator size. This size difference in $C$. canadensis suggests that prey and predators belonged to different age classes. In contrast to E. foordi, C. canadensis is a pelagic species (no evidence for benthic foraging) and it has been found only in seven beds throughout the formation. Thus, cannibalism in $C$. canadensis could be either the result of an intraspecific competition for the same resources, an opportunistic size-based predation or an opportunistic foraging behaviour (Ménard et al. 2006).

\section{Generalized Devonian estuarine conditions}

The Escuminac and Lode ecosystems have already been subjected to faunal comparisons owing to their similarities in terms of palaeogeography and palaeoenvironment (Schultze \& Cloutier 1996, Upeniece 2011). In our study, food web comparison shows also similar structures. Differences between these two assemblages and their trophic structure are due to minor changes in terms of taxonomic groups and potentially owing to different sampling efforts.

The time span between the oldest and the youngest beds of the Escuminac Formation is estimated between 59,500 years (based on sediment time recording) and 2.5 million years (based on spore biozonation estimations) (Cloutier et al. 2011). Stratigraphically, five or six transgressive and regressive phases are recorded throughout the Escuminac Formation (Cloutier et al. 2011). These different phases show trends in faunal assemblages that are characteristic of changing environment (i.e. regressive 
phases display a poorly diversified and/or structured faunal assemblage in comparison to transgressive phases). Bothriolepis canadensis, S. curta and E. foordi form an assemblage of three ubiquitous taxa (Cloutier et al. 2011) because of their presence throughout the formation independently of the transgressive or regressive phases. Thus, these three species likely played a major role in the structure of the food web and interspecies relationships. Because of the large timespan of the Escuminac Formation, a coordinate and evolutionary stasis (Brett et al. 1996, Ivany et al. 2009) has been suggested for the Escuminac assemblage (Cloutier et al. 2011). A long duration stasis is only possible if links between species are strong and explained by ecological stability and complexity as suggested by biostratigraphic distribution of taxa and the trophic structure of the Escuminac assemblage. According to DiMichele et al. (2004), ecological persistence can be explained by four hypotheses: (1) complex interspecies relationships (e.g. predation), (2) significant overlap of species environmental tolerances, (3) geographic isolation, and (4) the "law of large numbers" (i.e. the most abundant remain most abundant because they tend to produce more offspring than the less abundant species). Scaumenacia curta and E. foordi occurred throughout the formation, and E. foordi interacted (i.e. trophic interactions) with several species thus contributing to the stability of the assemblage (hypothesis 1). Environmental preferences, at least for one of the ubiquitous species (B. canadensis), are restricted, because it is a benthophageous species (Cloutier et al. 2011). Scaumenacia curta and E. foordi appeared to be pelagic as suggested by the ecomorphological analysis (Figs 6, 7). Therefore, there is neither an overlap of habitats (hypothesis 2) nor a geographic isolation (hypothesis 3). The relative abundance (hypothesis 4 ) of these species [B. canadensis, 37.24\%; S. curta, $12.54 \%$ and E. foordi, $16.97 \%$ (Cloutier et al. 2011)] is among the highest of the Escuminac assemblage. Finally, long term stasis owing to complex interspecies relationships (hypothesis 1), and more specifically trophic interactions, coupled with the high relative abundance (hypothesis 4 ) of these species could be an explanation to ecological persistence of this assemblage.

The environmental conditions of other Devonian ecosystems showed a generalized transition from a freshwater fauna to a saltwater fauna between the Early and Late Devonian (Schultze \& Cloutier 1996, Schultze 2013). Based on Middle and Late Devonian localities from England and Wales, Dineley (1999b) also documented this transition from freshwater to saltwater. Taxonomic groups, present in Escuminac and Lode Formations, have also been described from the estuarine palaeoenvironment of the Late Devonian Khovanian assemblage (Tula, Russia) by Lebedev (1992): e.g. antiarch placoderms (Asterolepis, Bothriolepis and Remigolepis), dipnoiforms (Grossipterus, Andreyev-
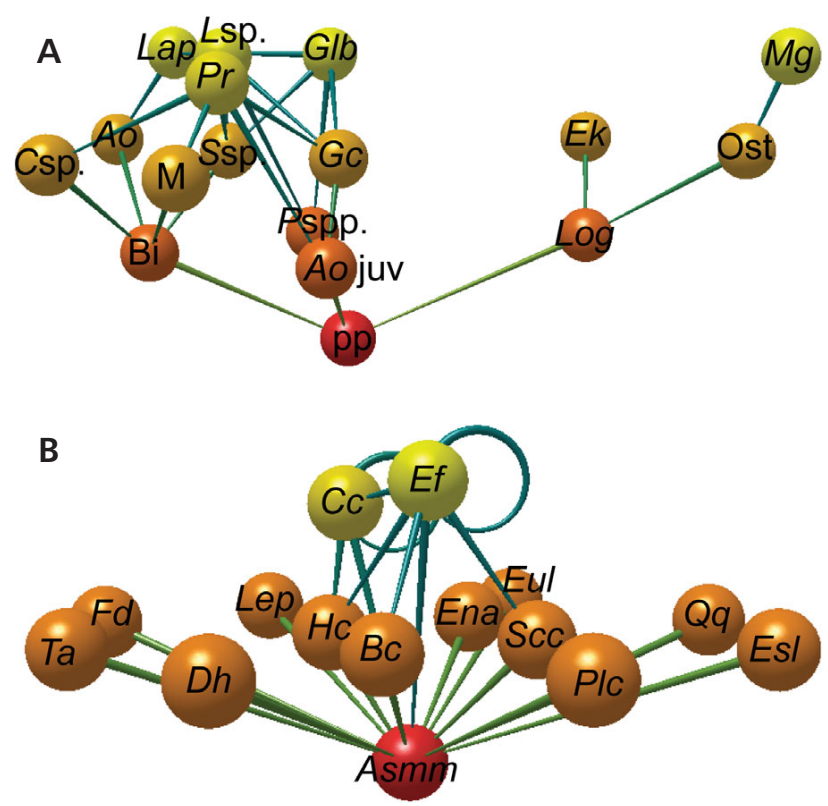

Figure 8. Three-dimensional trophic network representation of the Lode and Escuminac assemblages. - A - representation of the inferred model of the Lode assemblage based on Upeniece (2011) showing Panderichthys rhombolepis (Pr), Latvius sp. (Lsp), Glyptolepis baltica (Glb), Laccognathus panderi (Lap), Miguashaia grossi (Mg), Strunius sp. (Ssp), Asterolepis ornata (Ao), Cheirolepis sp. (Csp), Merostomata (M), Grossipterus crassus (Gc), Eusthenopteron kurshi (Ek), Osteolepididae indet. (Ost), benthic invertebrates (Bi), Asterolepis ornata juvenile (Ao juv), Psammolepis spp. (Pspp), Lodeacanthus gaujicus (Log), primary producers (pp). $\bullet \mathrm{B}$ - representation of the observed model for the Escuminac assemblage based on data presented in this paper showing Eusthenopteron foordi (Ef), Cheirolepis canadensis (Cc), Levesquaspis patteni (Lep), Fleurantia denticulata $(F d)$, Triazeugacanthus affinis $(T a)$, Bothriolepis canadensis (Bc), Endeiolepis aneri (Ena), Euphanerops longaevus (Eul), Homalacanthus concinnus (Hc), Diplacanthus horridus (Dh), Plourdosteus canadensis (Plc), Escuminaspis laticeps (Esl), Quebecius quebecensis (Qq), Scaumenacia curta (Scc), Asmusia membranacea (Asmm). Colours represent trophic levels: red, primary consumers/producers; orange, secondary consumers; yellow, predators. Loopings are for cannibalistic species.

ichthys, Scaumenacia and Fleurantia), tristichopterids (Eusthenopteron and Eusthenodon) and tetrapodomorphs and tetrapods (Tulerpeton, Panderichthys, Elpistostege). As evidence for the globalization of estuarine conditions throughout the Late Devonian, a comparison between the Khovanian and the Devonian Remigolepis-group (East Greenland) assemblages shows no significant differences in term of taxonomic groups (Lebedev 1992). Similar taxonomic compositions show similar trophic structures in response to similar environments.

Faunal diversification and disparification allowed the emergence of complex food webs (i.e. multiplication of interactions among species and diversification of trophic categories) and then the stability and persistence of species-rich past communities. Siluro-Devonian assemblages (Anderson et al. 2011) display a high anatomical diversity 
in several taxa. This geological period attests the evolutionary transition from agnathans to gnathostomes and most likely the establishment of Devonian vertebrate food webs. The emergence of complex vertebrate food webs occurred almost 200 million years later than the increasing complexity of the invertebrate food webs during the Early Cambrian (Vannier \& Chen 2005, Dunne et al. 2008, Klug et al. 2010, Vannier 2012).

\section{Conclusion}

Ecomorphological interpretation and identification of gut contents in Devonian vertebrates permitted us to accurately document the oldest vertebrate trophic networks. The recognition of global patterns of food webs, demonstrated for Middle to Late Devonian estuarine ecosystems, is based on similarities in terms of trophic network, taxonomic richness, phylogenetic diversity, and palaeogeography. Therefore, we conclude that faunal stability was already present during the Middle to Late Devonian. Notwithstanding this palaeoecological statism, both at a regional (i.e. within the Escuminac assemblage) and a continental scale (i.e. between the Escuminac and Lode assemblages), the evolutionary replacement of agnathans by gnathostomes (Anderson et al. 2011) as well as the transition from freshwater to saltwater faunas (Cloutier et al. 2011), and the Nekton revolution (Klug et al. 2010) are also recorded during the Devonian. The Frasnian/Fammenian crisis (approx. 375 Ma; Walker et al. 2012), punctuated by the Kellwasser event, did apparently not affect the vertebrate fauna fundamentally (Sallan \& Coates 2010). However, the Devonian/Carboniferous transition, punctuated by the Hangenberg event (approx. 359 Ma; Walker et al. 2012), is characterized by a distinct faunal turnover, where extant groups of vertebrates (e.g. chondrichthyans, actinopterygians, tetrapods) surpassed extinct groups of vertebrates (e.g. placoderms, acanthodians, basal sarcopterygians) and likely filled the gap at higher trophic levels. Throughout the Devonian, global changes (e.g. faunal turnover) are documented despite the stability of specific community but this hypothesis requires further testing by additional studies on other estuarine/marine ecosystems of this period. During early vertebrate history, complex communities of the Devonian were constrained by multiple trophic levels and size-based feeding interactions.

\section{Acknowledgements}

We thank Dominique Gravel (Université de Sherbrooke, Canada) for stimulating discussions in model construction. Jonathan Noël (NSERC Summer grant) helped with a preliminary selection of MHNM specimens. We thank Oleg Lebedev (Russian Academy of Sciences) and Ervīns Lukševičs (University of Latvia) for providing information concerning the Lode assemblage. John G. Maisey (AMNH) and Hervé Lelièvre (MNHM) provided specimen photographies. Johanne Kerr, Olivier Matton and France Charest provided access to the MHNM collection. Daniel Potvin-Leduc (Université du Québec à Rimouski) and Isabelle Béchard (Université du Québec à Rimouski) help with the figures. We are grateful to Hedvig Nenzén (Université du Québec à Rimouski) and Kévin Cazelles (Université du Québec à Rimouski) who provided comments on earlier versions of the manuscript. We thank Linda Frey (University of Zurich), Humberto Ferrón Jiménez (University of Valencia) and Christian Klug (University of Zurich) for constructive reviews on the manuscript. This project was funded by NSERC 238612 (Richard Cloutier).

\section{References}

AbLE, K.W. \& Fahay, M.P. 2010. Ecology of estuarine fishes. Temperate waters of the Western North Atlantic. 584 pp. Johns Hopkins University Press, Baltimore.

AhlBeRg, P.E. 1992. The palaeoecology and evolutionary history of the porolepiform sarcopterygians, 71-90. In Mark-Kurik, E. (ed.) Fossil Fishes as Living Animals. Estonian Academy of Sciences, Tallinn.

AlEXANDER, R.M. 1967. The functions and mechanisms of the protrusible upper jaws of some acanthopterygian fish. Journal of Zoology 151, 43-64.

DOI 10.1111/j.1469-7998.1967.tb02865.x

Alp, A., YeĞEn, V., Apaydin YaĞCi, M., Uysal, R., BiçEn, E. \& YAĞCI, A. 2008. Diet composition and prey selection of the pike, Esox lucius, in Civril Lake, Turkey. Journal of Applied Ichthyology 24, 670-677.

DOI 10.1111/j.1439-0426.2008.01119.x

Anderson, P.S.L., Friedman, M., Brazeau, M.D. \& Rayfield, E.J. 2011. Initial radiation of jaws demonstrated stability despite faunal and environmental change. Nature 476, 206-209. DOI 10.1038/nature10207

Arratia, G. \& Cloutier, R. 1996. Reassessment of the morphology of Cheirolepis canadensis (Actinopterygii), 165-197. In Schultze, H.P. \& Cloutier, R. (eds) Devonian Fishes and Plants of Miguasha, Quebec, Canada. Verlag Dr. Friedrich Pfeil, München.

Arreguín-SÁnchez, F. 2011. Ecosystem dynamics under 'top-down' and 'bottom-up' control situations generated by intensive harvesting rates. Hidrobiológica 21, 323-332.

Arsenault, M. 1982. Eusthenopteron foordi, a predator on Homalacanthus concinnus from the Escuminac formation, Miguasha, Quebec. Canadian Journal of Earth Sciences 19, 2214-2217. DOI 10.1139/e82-195

BАмвасH, R.K. 1999. Energetics in the global marine fauna: A connection between terrestrial diversification and change in the marine biosphere. Geobios 32, 131-144. DOI 10.1016/S0016-6995(99)80025-4

BAмBACH, R.K. 2002. Supporting predators: changes in the 
global ecosystem inferred from changes in predator diversity. Paleontological Society Papers 8, 319-351.

Barnes, C., Maxwell, D., Reuman, D.C. \& Jennings, S. 2010. Global patterns in predator-prey size relationships reveal size dependency of trophic transfer efficiency. Ecology 91, 222-232. DOI 10.1890/08-2061.1

Belles-Isles, M. 1992. The modes of swimming of sarcopterygians, 117-130. In MARK-KuRIK, E. (ed.) Fossil Fishes as Living Animals. Estonian Academy of Sciences, Tallinn.

Boucot, A.J. 1990. Evolutionary paleobiology of behavior and coevolution. Elsevier, Amsterdam \& New York.

Brett, C.E., Ivany, L.C. \& Schopf, K.M. 1996. Coordinated stasis: An overview. Palaeogeography, Palaeoclimatology, Palaeoecology 127, 1-20.

DOI 10.1016/S0031-0182(96)00085-5

Breusch, T.S. \& Pagan, A.R. 1979. A simple test for heteroscedasticity and random coefficient variation. Econometrica 47, 1287-1294. DOI 10.2307/1911963

Brose, U., Jonsson, T., Berlow, E.L., Warren, P., Banasek-Richter, C., Bersier, L.F., Blanchard, J.L., Brey, T., Carpenter, S.R., Cattin Clandenier, M.F., Cushing, L., Ali Dawah, H., Dell, T., Edwards, F., Harper-Smith, S., Jacob, U., Ledger, M.E., Martinez, N.D., Memmott, J., Mintenbeck, K., Pinnegar, J.K., Rall, B.C., Rayner, T.S., Reuman, D.C., Ruess, L., Ulrich, W., Williams, R.J., WoodWARD, G. \& COHEN, J.E. 2006. Consumer-resource body-size relationships in natural food webs. Ecology 87, 2411-2417. DOI 10.1890/0012-9658(2006)87[2411:CBRINF]2.0.CO;2

Carrano, M.T. \& Velez-Juarbe, J. 2006. Paleoecology of the Quarry 9 vertebrate assemblage from Como Bluff, Wyoming (Morrison Formation, Late Jurassic). Palaeogeography, Palaeoclimatology, Palaeoecology 237, 147-159. DOI 10.1016/j.palaeo.2005.11.018

Cazelles, K., Araújo, M.B., Mouquet, N. \& Gravel, D. 2016. A theory for species co-occurrence in interaction networks. Theoretical Ecology 9, 39-48. DOI 10.1007/s12080-015-0281-9

Clifton, K.B. \& MotTA, P.J. 1998. Feeding morphology, diet, and ecomorphological relationships among five caribbean labrids (Teleostei, Labridae). Copeia 1998, 953-966. DOI $10.2307 / 1447342$

Cloutier, R. 2010. The fossil record of fish ontogenies: Insights into developmental patterns and processes. Seminars in Cell \& Developmental Biology 21, 400-413. DOI 10.1016/j.semcdb.2009.11.004

Cloutier, R. 2013. Great Canadian Lagerstätten 4. The Devonian Miguasha biota (Québec): UNESCO World Heritage Site and a time capsule in the early history of vertebrates. Geoscience Canada 40, 149-163. DOI 10.12789/geocanj.2013.40.008

Cloutier, R., Béchard, I., Charest, F. \& Matton, O. 2009. La contribution des poissons fossiles du parc national de Miguasha à la biologie évolutive du développement. Le naturaliste canadien 133, 84-95.

Cloutier, R., Loboziak, S., Candilier, A.M. \& Blieck, A. 1996. Biostratigraphy of the Upper Devonian Escuminac Formation, eastern Québec, Canada: A comparative study based on miospores and fishes. Review of Palaeobotany and Palynology 93, 191-215.

DOI 10.1016/0034-6667(95)00126-3

Cloutier, R., Proust, J.N. \& Tessier, B. 2011. The Miguasha Fossil-Fish-Lagerstätte: A consequence of the Devonian land-sea interactions. Palaeobiodiversity and Palaeoenvironments 91, 293-323. DOI 10.1007/s12549-011-0058-0

Cohen, J.E., Pimm, S.L., Yodzis, P. \& Saldaña, J. 1993. Body sizes of animal predators and animal prey in food webs. Journal of Animal Ecology 62, 67-78. DOI 10.2307/5483

Costanza, R., Arge, R. D', Groot, R. de, Farber, S., Grasso, M., Hannon, B., Limburg, K., Naeem, S., O’Neill, R.V, Paruelo, J., Raskin, R.G., Sutton, P. \& Van den Belt, M. 1997. The value of the world's ecosystem services and natural capital. Nature 387, 253-260. DOI 10.1038/387253a0

Covich, A.P., Palmer, M.A. \& Crowl, T.A. 1999. The role of benthic invertebrate species in freshwater ecosystems, zoobenthic species influence energy flows and nutrient cycling. Bioscience 49, 119-127. DOI 10.2307/1313537

Crabtree, R.E., Stevens, C., Snodgrass, D. \& Stengard, F.J. 1998. Feeding habits of bonefish, Albula vulpes, from the waters of the Florida Keys. Fishery bulletin 96, 754-766.

DAVIDSON, R.G. \& TREwIN, N.H. 2005. Unusual preservation of the internal organs of acanthodian and actinopterygian fish in the Middle Devonian of Scotland. Scottish Journal of Geology 41, 129-134. DOI 10.1144/sjg41020129

DiMichele, W.A., Behrensmeyer, A.K., Olszewski, T.D., Labandeira, C.C., Pandolfi, J.M., Wing, S.L. \& Bobe, R. 2004. Long-term stasis in ecological assemblages: Evidence from the fossil record. Annual Review of Ecology, Evolution, and Systematics 35, 285-322.

DOI 10.1146/annurev.ecolsys.35.120202.110110

Dineley, D.L. 1999a. British Carboniferous fossil fishes sites, 265-312. In Dineley, D.L. \& Metcalf, S.J. (eds) Fossil Fishes of Great Britain. Joint Nature Conservation Committee, Peterborough.

Dineley, D.L. 1999b. Mid- and late Devonian fossil fishes sites of England and Wales, 225-226. In Dineley, D.L. \& Metcalf, S.J. (eds) Fossil Fishes of Great Britain, Joint Nature Conservation Comittee, Peterborough.

DunNe, J. 2009. Food webs, 3661-3682. In MeYers, R.A. (ed.) Encyclopedia of Complexity and Systems Science. Springer, New York.

Dunne, J., Williams, R.J., Martinez, N.D., Wood, R.A. \& ERwin, D.H. 2008. Compilation and network analyses of Cambrian food webs. PLoS Biology 6, 693-708. DOI 10.1371/journal.pbio.0060102

Durbin, J. \& WATSON, G.S. 1971. Testing for serial correlation in least squares regression. III. Biometrika 58, 1-19. DOI 10.1093/biomet/58.1.1

Elliott, M., Hemingway, K.L., Costello, M.J., Duhamel, S., Hostens, K., Labropoulou, M., Marshall, S. \& Winkler, H. 2002. Links between fish and other trophic levels, 124-216. In Elliott, M. \& Hemingway, K.L. (eds) Fishes in Estuaries. Blackwell Science, Oxford. 
Emmerson, M.C. \& Raffaeldi, D. 2004. Predator-prey body size, interaction strength and the stability of a real food web. Journal of Animal Ecology 73, 300-409. DOI 10.1111/j.0021-8790.2004.00818.x

Frey, E. \& Tischlinger, H. 2012. The Late Jurassic pterosaur Rhamphorhynchus, a frequent victim of the ganoid fish Aspidorhynchus? PLoS ONE 7, e31945. DOI 10.1371/journal.pone.0031945

Gensel, P.G. \& Barnett-Lawrence, M. 1996. Plant megafossils from the Escuminac Formation, 79-90. In Schultze, H.P. \& Cloutier, R. (eds) Devonian Fishes and Plants of Miguasha, Quebec, Canada. Dr. Friedrich Pfeil, München.

HabGOOD, K.S., Hass, H. \& KeRP, H. 2003. Evidence for an early terrestrial food web: Coprolites from the Early Devonian Rhynie chert. Transactions of the Royal Society of Edinburgh: Earth Sciences 94, 371-389. DOI 10.1017/S0263593300000754

Hammer, O., Harper, D.A.T. \& Ryan, P.D. 2001. PAST: Paleontological statistics software: Package for education and data analysis. Palaeontologia Electronica 4.

Hunter, M.D. \& Price, P.W. 1992. Playing chutes and ladders: Heterogeneity and the relative roles of bottom-up and top-down forces in natural communities. Ecology 73, 724-732.

IтоH, T. \& SAKaI, O. 2016. Open-ocean foraging ecology of southern bluefin tuna Thunnus maccoyii based on stomach contents. Marine Ecology Progress Series 555, 203-219. DOI 10.3354/meps 11810

Ivany, L.C., Brett, C.E., Wall, H.L.B., Wall, P.D. \& Handley, J.C. 2009. Relative taxonomic and ecologic stability in Devonian marine faunas of New York State: a test of coordinated stasis. Paleobiology 35, 499-524.

DOI 10.1666/0094-8373-35.4.499

JANVIER, P. 1996. Early vertebrates. 396 pp. Oxford University Press, Oxford.

Jennings, S., Pinnegar, J.K., Polunin, N.V.C. \& Boon, T.W. 2001. Weak cross-species relationships between body size and trophic level belie powerful size-based trophic structuring in fish communities. Journal of Animal Ecology 70, 934-944. DOI 10.1046/j.0021-8790.2001.00552.x

Jeram, A.J. 1996. Chelicerata from the Escuminac Formation, 103-111. In Schultze, H.P. \& Cloutier, R. (eds) Devonian Fishes and Plants of Miguasha, Quebec,Canada. Dr. Friedrich Pfeil, München.

Jurina, A. \& Raskatova, M. 2012. New data on the Devonian plant and miospores from the Lode formation, Latvia. Zemes un vides zinātnes $783,46-56$.

Klug, C., Kroegger, B., Kiessling, W., Muluins, G.L., Servais, T., Fryda, J., Korn, D. \& Turner, S. 2010. The Devonian nekton revolution. Lethaia 43, 465-477. DOI 10.1111/j.1502-3931.2009.00206.x

Kriwet, J., Witzmann, F., KLug, S. \& Heidtke, U.H.J. 2008. First direct evidence of a vertebrate three-level trophic chain in the fossil record. Proceedings of the Royal Society of London B: Biological Sciences 275, 181-186.

DOI 10.1098/rspb.2007.1170
Labropoulou, M. \& Eleftheriou, A. 1997. The foraging ecology of two pairs of congeneric demersal fish species: Importance of morphological characteristics in prey selection. Journal of Fish Biology 50, 324-340.

DOI 10.1111/j.1095-8649.1997.tb01361.x

Lebedev, O.A. 1992. The latest Devonian, Khovanian vertebrate assemblage of Andreyevka-2 locality, Tula Region, Russia, 265-272. In MARK-KuriK, E. (ed.) Fossil Fishes as Living Animals. Estonian Academy of Sciences, Tallinn.

Legendre, L. \& Legendre, P. 1979. Écologie numérique. Vol. 1. xiv + 197 pp. Masson, Paris et les Presses de l'Université du Québec, Québec.

LouYs, J., Wilkinson, D.M. \& Bishop, L.C. 2012. Ecology needs a paleontological perspective, 23-38. In LouYs, J. (ed.) Paleontology in Ecology and Conservation, Springer, Berlin.

LuKŠEviČs, E. 1992. Palaeoichthyocenoses of the Famennian brackish seas of the Baltic area, 273-280. In MARK-KuRIK, E. (ed.) Fossil Fishes as Living Animals. Estonian Academy of Sciences, Tallinn.

Lund, R., Greenfest-Allen, E. \& Grogan, E. 2014. Ecomorphology of the Mississippian fishes of the Bear Gulch Limestone (Heath formation, Montana, USA). Environmental Biology of Fishes 98, 1-16.

MAISEY, J.G. 1994. Predator-prey relationships and trophic level reconstruction in a fossil fish community. Environmental Biology of Fishes 40,1-22. DOI 10.1007/BF00002179

MAPLES, C.G. 1996. Paleoenvironmental significance of trace fossils in the Escuminac Formation, 114-119. In Schultze, H.P. \& Cloutier, R. (eds) Devonian Fishes and Plants of Miguasha, Quebec, Canada. Dr. Friedrich Pfeil, München.

MARK-KURIK, E. 1995. Trophic relations of Devonian fishes. Geobios 19, 121-123. DOI 10.1016/S0016-6995(95)80098-0

Martens, T. 1996. Conchostraca (Phyllopoda, Crustacea) from the Escuminac Formation, 112-113. In Schultze, H.P. \& Cloutier, R. (eds) Devonian Fishes and Plants of Miguasha, Quebec, Canada. Dr. Friedrich Pfeil, München.

McQueEn, D.J., Johannes, M.R.S., Post, J.R., Stewart, T.J. \& LEAN, D.R.S. 1989. Bottom-up and top-down impacts on freshwater pelagic community structure. Ecological Monographs 59, 289-309. DOI 10.2307/1942603

Ménard, F., Labrune, C., Shin, Y.J., Asine, A.S. \& Bard, F.X. 2006. Opportunistic predation in tuna: A size-based approach. Marine Ecology Progress Series 323, 223-231. DOI 10.3354/meps323223

Menge, B.A. 2000. Top-down and bottom-up community regulation in marine rocky intertidal habitats. Journal of Experimental Marine Biology and Ecology 250, 257-289. DOI 10.1016/S0022-0981(00)00200-8

Mitchell, J.S., Roopnarine, P.D. \& AngielczyK, K.D. 2012. Late Cretaceous restructuring of terrestrial communities facilitated the end-Cretaceous mass extinction in North America. Proceedings of the National Academy of Sciences 109, 18857-18861. DOI 10.1073/pnas.1202196109

MotTA, P.J. 1984. Mechanics and functions of jaw protrusion in teleost fishes: A review. Copeia 1984, 1-18. DOI $10.2307 / 1445030$ 
Nenzén, H.K., Montoya, D. \& Varela, S. 2014. The Impact of 850,000 Years of Climate Changes on the Structure and Dynamics of Mammal Food Webs. PLoS ONE 9, e106651. DOI 10.1371/journal.pone.0106651

Nesbitt, S.J., Turner, A.H., Erickson, G.M. \& Norell, M.A. 2006. Prey choice and cannibalistic behaviour in the theropod Coelophysis. Biology Letters 2, 611-614. DOI 10.1098/rsbl.2006.0524

Nicolas, D., Lobry, J., Lepage, M., Sautour, B., Le Pape, O., Cabral, H., Uriarte, A. \& Bö̈t, P. 2010. Fish under influence: A macroecological analysis of relations between fish richness and environmental gradient among European tidal estuaries. Estuarine Coastal and Shelf Science 86, 137-147. DOI 10.1016/j.ecss.2009.11.006

NiLsson, P.A. \& BRÖNMARK, C. 2000. Prey vulnerability to a gape-size limited predator: behavioural and morphological impacts on northern pike piscivory. Oikos 88, 539-546. DOI 10.1034/j.1600-0706.2000.880310.x

NovitSKAYA, L.I. 1992. Heterostracans: Their ecology, internal structure and ontogeny, 51-59. In MARK-KURIK, E. (ed.) Fossil Fishes as Living Animals. Estonian Academy of Sciences, Tallinn.

Parent, N. \& Cloutier, R. 1996. Distribution and preservation of fossils in the Escuminac Formation, 54-78. In Schultze, H.P. \& Cloutier, R. (eds.) Devonian Fishes and Plants of Miguasha, Quebec, Canada. Verlag Dr Friedrich Pfeil, München.

Peters, R.H. 1983. Ingestion, 100-117. In Beck, E., Birks, H.J.B. \& Connor, E.F. (eds) The Ecological Implication of Body Size. Cambridge University Press, Cambridge.

Peterson, M.S. 2003. A conceptual view of environment-habitat-production linkages in tidal river estuaries. Reviews in Fisheries Science 11, 291-313.

DOI 10.1080/10641260390255844

Pontén, A. \& Plink-Björklund, P. 2007. Depositional environments in an extensive tide-influenced delta plain, Middle Devonian Gauja Formation, Devonian Baltic Basin. Sedimentology 54, 969-1006. DOI 10.1111/j.1365-3091.2007.00869.x

Popović, M. \& Gottstein-Matočec, S. 2006. Biological aspects of the spinicaudata (Branchiopoda, Diplostraca) in the largest alluvial wetland in Croatia. Crustaceana 79, 423-440. DOI 10.1163/156854006777554811

ReIMCHEN, T.E. 1991. Evolutionary attributes of headfirst prey manipulation and swallowing in piscivores. Canadian Journal of Zoology 69, 2912-2916. DOI 10.1139/z91-410

Reuman, D.C., Holt, R.D. \& Yvon-Durocher, G. 2014. A metabolic perspective on competition and body size reductions with warming. Journal of Animal Ecology 83, 59-69. DOI 10.1111/1365-2656.12064

RipPle, W.J., RoOney, T.P. \& BeschtA, R.L. 2010. Large predators, deer, and trophic cascades in boreal and temperate ecosystems. In Terborgh, J. \& Estes, J.A. (eds) Trophic Cascades. Island Press, Washington D.C.

Romanuk, T.N., Hayward, A. \& Hutchings, J.A. 2010. Trophic level scales positively with body size in fishes. Global Ecol- ogy and Biogeography20, 231-240.

DOI 10.1111/j.1466-8238.2010.00579.x

SAllan, L.C. \& COATES, M.I. 2010. End-Devonian extinction and a bottleneck in the early evolution of modern jawed vertebrates. Proceedings of the National Academy of Sciences 107, 10131-10135. DOI 10.1073/pnas.0914000107

SCHAEFFER, B. \& Rosen, D.E. 1961. Major adaptive levels in the evolution of the actinopterygian feeding mechanism. American Zoologist 1, 187-204. DOI 10.1093/icb/1.2.187

Scharf, F.S., Junnes, F. \& Rountree, R.A. 2000. Predator size-prey size relationships of marine fish predators: interspecific variation and effects of ontogeny and body size on trophic-niche breadth. Marine Ecology Progress Series 208, 229-248. DOI 10.3354/meps208229

Schultze, H.P. 1999. The fossil record of the intertidal zone, 375-392. In Horn, M.H., Martin, K.L.M. \& С Соtкowski, M.A. (eds) Intertidal Fishes: Life in Two Worlds. Elsevier.

Schultze, H.P. 2013. The paleoenvironment at the transition from piscine to tetrapod sarcopterygians, 373-397. In LuCAS, S.G. (ed.) The Carboniferous-Permian Transition, Vol. 60. New Mexico Museum of Natural History and Science, Albuquerque.

Schultze, H.P. \& Cloutier, R. 1996. Comparison of the Escuminac Formation ichthyofauna with other late Givetian/early Frasnian ichthyofaunas, 348-366. In Schultze, H.P. \& Cloutier, R. (eds) Devonian Fishes and Plants of Miguasha, Quebec, Canada. Dr. Friedrich Pfeil, München.

Sennikov, A.G. 1996. Evolution of the Permian and Triassic tetrapod communities of Eastern Europe. Palaeogeography, Palaeoclimatology, Palaeoecology 120, 331-351.

DOI 10.1016/0031-0182(95)00041-0

SHAPIRO, S.S. \& WiLK, M.B. 1965. An analysis of variance test for normality (complete samples). Biometrika 52, 591-611. DOI 10.1093/biomet/52.3-4.591

Smith, C. \& Reay, P. 1991. Cannibalism in teleost fish. Reviews in Fish Biology and Fisheries 1, 41-64. DOI 10.1007/BF00042661

Trewin, N.H. 1985. Mass mortalities of Devonian fish - the Achanarras Fish Bed, Caithness. Geology Today 1(2), 46-49. DOI 10.1111/j.1365-2451.1985.tb00432.x

Upeniece, I. 2001. The unique fossil assemblage from the Lode Quarry (Upper Devonian, Latvia). Fossil Record 4(1), 101-119. DOI 10.5194/fr-4-101-2001

UPENIECE, I. 2011. Palaeoecology and juvenile individuals of the Devonian placoderm and acanthodian fishes from Lode site, Latvia. Ph.D. thesis, University of Latvia, Riga, Latvia.

VANNIER, J. 2012. Gut contents as direct indicators for trophic relationships in the Cambrian marine ecosystem. PLOS ONE 7, e52200. DOI 10.1371/journal.pone.0052200

VANNiER, J. \& Chen, J. 2005. Early Cambrian food chain: New evidence from fossil aggregates in the Maotianshan shale biota, SW China. Palaios 20, 3-26.

DOI 10.2110/palo.2003.p03-40

WAinwright, P.C. \& RichaRD, B.A. 1995. Predicting patterns of prey use from morphology of fishes. Environmental Biology of Fishes 44, 97-113. DOI 10.1007/BF00005909 
Walker, J.D., Geissman, J.W., Bowring, S.A. \& Babcock, L.E. 2012. Geologic Time Scale v. 4.0. The Geological Society of America, Boulder.

WANG, X., MiaO, D. \& Zhang, Y. 2005. Cannibalism in a semiaquatic reptile from the Early Cretaceous of China. Chinese Science Bulletin 50, 282-284. DOI 10.1007/BF02897540

Westneat, M.W. 2004. Evolution of levers and linkages in the feeding mechanisms of fishes. Integrative and Comparative Biology 44, 378-389. DOI 10.1093/icb/44.5.378

Willis, S.C., Winemiller, K.O. \& Lopez-Fernandez, H. 2005. Habitat structural complexity and morphological diversity of fish assemblages in a Neotropical foodplain river. Oecologica 142, 284-295. DOI 10.1007/s00442-004-1723-z

Wilson, H.M., Daeschler, E.B. \& Desbiens, S. 2005. New flat-backed archipolypodan millipedes from the Upper Devon- ian of North America. Journal of Paleontology 79, 738-744. DOI 10.1666/0022-3360(2005)079[0738:NFAMFT]2.0.CO;2

Woodward, G., Ebenman, B., Emmerson, M., Montoya, J.M., Olesen, J.M., VALido, A. \& WARREN, P.H. 2005. Body size in ecological networks. Trends in Ecology \& Evolution 20, 402-409. DOI 10.1016/j.tree.2005.04.005

Wootton, R.J. 1992. Feeding and growth, 98-131. In Wootton, R.J. (ed.) Fish Ecology. Springer, Berlin.

Yodzis, P. \& InNES, S. 1992. Body size and consumer-resource dynamics. The American Naturalist 139, 1151-1175. DOI $10.1086 / 285380$

ZupIN̦Š, I. 2008. A new tristichopterid (Pisces, Sarcopterygii) from the Devonian of Latvia. Proceedings of the Latvian Academy of Sciences. Section B. Natural, Exact, and Applied Sciences 62, 40-46. DOI 10.2478/v10046-008-0007-0 